Campbell University School of Law

Scholarly Repository @ Campbell University School of Law

2012

\title{
Anti-Evasion Doctrines in Constitutional Law
}

Michael B. Kent Jr.

Campbell University School of Law, mkent@campbell.edu

Brannon P. Denning

Follow this and additional works at: https://scholarship.law.campbell.edu/fac_sw

Part of the Constitutional Law Commons

\section{Recommended Citation}

Michael B. Kent Jr. \& Brannon P. Denning, Anti-Evasion Doctrines in Constitutional Law, 2012 Utah L. Rev. 1773 (2012).

Available at: https://scholarship.law.campbell.edu/fac_sw/92

This Article is brought to you for free and open access by the Faculty Scholarship at Scholarly Repository @ Campbell University School of Law. It has been accepted for inclusion in Scholarly Works by an authorized administrator of Scholarly Repository @ Campbell University School of Law. 


\title{
ANTI-EVASION DOCTRINES IN CONSTITUTIONAL LAW
}

\author{
Brannon P. Denning* \& Michael B. Kent, Jr.**
}

Abstract

Recent constitutional scholarship has focused on how courts-the Supreme Court in particular- "implements" constitutional meaning through the use of doctrinal constructs that enable judges to decide cases. Judges first fix constitutional meaning, what Mitchell Berman terms the "constitutional operative proposition," but must then design "decision rules" that render the operative proposition suitable to use in the third step, the resolution of the case before the court. These decision rules produce the familiar apparatus of constitutional decisionmaking-strict scrutiny, rational basis review, and the like. For the most part, writers have adopted a binary view of doctrine. Doctrinal tests can defer or not to other actors; implementing doctrines can be fashioned as rules or standards; doctrines can overenforce or underenforce constitutional commands. In this Article, though, we unsettle this dialectical view of doctrinal design by identifying and describing antievasion doctrines (AEDs) in constitutional law: doctrines developed by courts-usually designed as standards, as opposed to rules-that supplement other doctrines (designed as rules) to implement particular constitutional principles.

$A E D$ s touch all areas of constitutional law. In addition to being ubiquitous, AEDs have a long pedigree. Early examples appear in famous Marshall Court opinions; thus, they are not some modern innovation. In addition to naming $A E D s$, describing the forms they take, and discussing the characteristics the forms share, this Article also seeks to describe the benefits and costs to constitutional law resulting from $A E D s$, as well as their implications for doctrinal formation more generally.

We back our claim about the omnipresence and pedigree of $A E D$ s in Part II with examples from a broad swath of constitutional law. AEDs supplement rule-like decision rules with decision rules that tend to resemble standards. In Part III we discuss the benefits of AEDs and the tradeoffs for doctrine in their widespread use. AEDs are designed to

* (C) 2012 Brannon P. Denning. Professor, Cumberland School of Law, Samford University. Research on this Article was sponsored by a generous summer grant from the Cumberland School of Law.

** (C) 2012 Michael B. Kent, Jr. Associate Professor, Atlanta's John Marshall Law School. Thanks to Ben Barton, Joseph Blocher, Beth Burch, Dan Coenen, Mike Greve, John Harrison, Lou Virelli, Eugene Volokh, and Norman Williams for helpful comments. Katie Terry provided valuable research assistance. 
help optimize enforcement of constitutional principles-by addressing "problems with rules," for example. This gap-filling function comes at a cost, however. Not only does the addition of AEDs tend to increase doctrinal complexity, but that complexity can also increase decision costs for courts and dilute the benefits of using rules in the first place. The tradeoffs are almost mirror images of the benefits.

We discuss the implications of AEDs for constitutional doctrine generally in Part $I V$. That they seem to be everywhere in constitutional law suggests that doctrinal complexity should be seen as a feature of our system, not a bug, because it attempts to ensure form will not trump constitutional substance. If a certain amount of complexity is inevitable, then that suggests one should be skeptical about claims that constitutional law could be rationalized by abandoning the "formulaic Constitution" in favor of simple, predictable, and easy-to-apply rules. Further, the presence of AEDs furnishes strong evidence for Frederick Schauer's "convergence hypothesis," which holds that "[w]hen authorised to act in accordance with rules, rule-subjects will tend to convert rules into standards by employing a battery of rule-avoiding devices that serve to soften the hard edges of rules," and vice-versa. Finally, highlighting the role AEDs play in constitutional doctrine, for good or ill, is another reason to take doctrine, its formation, and application by courts, seriously.

"The Constitution deals with substance, not shadows. Its inhibition was levelled at the thing, not the name. It intended that the rights of the citizen should be secure against deprivation for past conduct by legislative enactment, under any form, however disguised. If the inhibition can be evaded by the form of the enactment, its insertion in the fundamental law was a vain and futile proceeding."

"[T] he [C]ourt must be vigilant to scrutinize the attendant facts with an eye to . . prevent violations of the Constitution by circuitous and indirect methods. ${ }^{2}$

"[T] he Constitution is concerned, not with form, but with substance."

"The [Fifteenth] Amendment nullifies [both] sophisticated as well as simple-minded modes of discrimination. ${ }^{, 4}$

\footnotetext{
${ }^{1}$ Cummings v. Missouri, 71·U.S. (4 Wall.) 277, 325 (1867).

${ }^{2}$ Byars v. United States, 273 U.S. 28, 32 (1927).

${ }^{3}$ Gasoline Prods. Co. v. Champlin Ref. Co., 283 U.S. 494, 498 (1931).

${ }^{4}$ Lane v. Wilson, 307 U.S. 268, 275 (1939).
} 
"The [C]ommerce [C]lause forbids discrimination, whether forthright or ingenious." "s

\section{INTRODUCTION}

Recent constitutional scholarship has focused on how courts-the Supreme Court in particular- "implement" constitutional meaning through the use of doctrinal constructs that enable judges to decide cases. ${ }^{6}$ Whereas more conventional accounts of constitutional adjudication portrayed it as involving two steps - the interpretation of the Constitution and the application of that interpretation to reach a constitutional holding - the "two-output" thesis posits that constitutional adjudication proceeds in three steps. ${ }^{8}$ Judges first fix constitutional meaning, what Professor Berman terms the "constitutional operative proposition," but must then design "decision rules" that render the operative proposition suitable to use in the third step, the resolution of the case before the court. ${ }^{9}$ These decision rules produce the familiar apparatus of constitutional decision-making - strict scrutiny, rational basis review, and the like.

${ }^{5}$ Best \& Co. v. Maxwell, 311 U.S. 454, 455 (1940).

${ }^{6}$ See Richard H. FAllon, JR., ImPlementing the CONSTitution 7-101 (2001) (cataloguing and analyzing how the Supreme Court applies seven different doctrinal tests); Mitchell N. Berman, Constitutional Decision Rules, 90 VA. L. REV. 1 (2004); Kermit Roosevelt III, Constitutional Calcification: How the Law Becomes What the Court Does, 91 VA. L. REV. 1649 (2005); see also Dan T. Coenen, A Constitution of Collaboration: Protecting Fundamental Values with Second-Look Rules of Interbranch Dialogue, 42 WM. \& MARY L. REV. 1575, 1582 (2001) (discussing the structural rules used in constitutional decisionmaking); Dan T. Coenen, The Rehnquist Court, Structural Due Process, and Semisubstantive Constitutional Review, 75 S. CAL. L. REV. 1281, 1284 (2002) (examining how the Rehnquist Court has applied semisubstantive doctrines); Matthew C. Stephenson, The Price of Public Action: Constitutional Doctrine and the Judicial Manipulation of Legislative Enactment Costs, 118 YALE L.J. 2, 4 (2008) (arguing that courts should protect constitutional guarantees by using doctrines designed to raise the cost to government decisionmakers who enact unconstitutional policies). For work that uses the two-output thesis in specific subject areas, see, for example, Robert M. Chesney, National Security Fact Deference, 95 VA. L. REV. 1361 (2009); Brannon P. Denning, Reconstructing the Dormant Commerce Clause Doctrine, 50 WM. \& MARY L. REv. 417 (2008); Arthur Leavens, Prophylactic Rules and State Constitutionalism, 44 SUFFOLK U. L. REV. 415 (2011); and Garrick B. Pursley, Dormancy, 100 GEO. L.J. 497 (2012).

${ }^{7}$ Berman, supra note 6, at 32-33.

${ }^{8}$ See Mitchell N. Berman, Aspirational Rights and the Two-Output Thesis, 119 HARV. L. REV. F. 220, 221 (2006), available at http://hlr.rubystudio.com/media/pdf/ berman.pdf.

${ }^{9}$ Berman, supra note 8 , at 221. 
Scholars of this "new doctrinalism"10 have emphasized the discretion courts exercise when designing doctrine to implement meaning. ${ }^{11}$ Professor Fallon, for example, has identified the various doctrinal tests the Court employs when adjudicating cases. ${ }^{12}$ Professors Berman and Roosevelt separately have identified factors that influence decisionmakers to choose one doctrinal test over another. ${ }^{13}$

For the most part, writers have adopted a dualist view of doctrine. Doctrinal tests can defer or not to other actors; ${ }^{14}$ implementing doctrines can be fashioned as rules or standards; ${ }^{15}$ doctrines can overenforce or underenforce constitutional commands. $^{16}$

In this Article, we attempt to unsettle this dialectical view of doctrinal design by identifying and describing anti-evasion doctrines (AEDs) in constitutional law. AEDs are doctrines developed by courts-usually designed as standards, as opposed to rules-that supplement other doctrines (designed as rules) to implement particular constitutional principles. Specifically, AEDs seek to prevent officials from complying with the form of the previously announced rule, while subverting the substance of the constitutional principle the rule sought to implement. Put differently, they attempt to optimize constitutional enforcement by curbing circumvention of constitutional principles.

Two brief examples of AEDs illustrate the concept. ${ }^{17}$ Under the dormant Commerce Clause doctrine, the Court has traditionally employed an antidiscrimination rule ${ }^{18}$ to overenforce the constitutional principle that states may not interfere with interstate commerce in ways that undermine or inhibit national

${ }^{10}$ Brannon P. Denning, The New Doctrinalism in Constitutional Scholarship and District of Columbia v. Heller, 75 TENN. L. REV. 789, 790 (2008). As indicated, we use the term "new doctrinalism" to refer to recent scholarship that focuses on the Court's creation and application of devices to implement the Constitution's meaning. We view this Article as building on and contributing to this trend.

${ }^{11}$ See, e.g., Berman, supra note 6, at 92-96; Roosevelt, supra note 6, at 1658-67.

${ }^{12}$ See FALLON, supra note 6, at 77-79.

${ }^{13}$ See, e.g., Berman, supra note 6, at 92-96; Roosevelt, supra note 6, at 1658-67.

${ }^{14}$ See, e.g., KERMIT RoOSEVELT III, ThE MYTH OF JudicIAL ACTIVISM 174 (2005).

${ }^{15}$ See, e.g., Kathleen M. Sullivan, The Supreme Court, 1991 Term-Foreword: The Justices of Rules and Standards, 106 HARV. L. REV. 22, 56-95 (1992).

${ }^{16}$ Berman, supra note 6, at 133-36; see also David A. Strauss, The Ubiquity of Prophylactic Rules, 55 U. CHI. L. REV. 190, 190 (1988) (““[P]rophylactic' rules are not exceptional measures of questionable legitimacy but are a central and necessary feature of constitutional law.").

${ }^{17}$ Although we note a number of constitutional areas in which AEDs occur, we rely on the dormant Commerce Clause doctrine and regulatory takings throughout this Article to illustrate many of our points. There are several reasons for that reliance. First, both of these doctrines are famously complex and have garnered complaints from scholars, judges, and practitioners alike. Second, and related to their complexity, anti-evasion principles seem to lie at the very core of what these doctrines are designed to accomplish. Finally, our prior individual work has focused chiefly on these two doctrines, and for that reason, we know them best and have spent the most time thinking about them.

${ }^{18}$ See, e.g., Philadelphia v. New Jersey, 437 U.S. 617, 624, 628-29 (1978). 
political unity. ${ }^{19}$ This rule holds that states may not treat out-of-state goods or economic actors worse than their in-state counterparts based on geographic origin. Were the Court to ban only facial discrimination, however, government actors could evade the antidiscrimination rule simply by crafting discriminatory laws in geographically neutral terms. To forestall this evasion-which undermines the constitutional principle the antidiscrimination rule is meant to implement-the Court treats laws enacted with a discriminatory purpose or having discriminatory effects as if they were facially discriminatory and subjects them to the same strict or heightened scrutiny. ${ }^{20}$ These purpose and effects inquiries are examples of AEDs.

Consider also the constitutional command that "private property [shall not] be taken for public use, without just compensation,"21 which has been enforced most directly through decision rules that closely track that command. Thus, the Court has required governments both to have a public purpose ${ }^{22}$ and to tender compensation ${ }^{23}$ when appropriating private property through eminent domain. ${ }^{24}$ But if only direct condemnation triggered the takings protections, the government easily could skirt the constitutional imperative through other means-such as regulation-equally injurious to property rights. ${ }^{25}$ To prevent this result, the Court has held that regulations having sufficiently onerous effects to qualify as "functionally equivalent" to a direct appropriation also trigger the takings protections. ${ }^{26}$ Moreover, although the government may impose certain onerous conditions on land use to serve a legitimate state interest, those conditions must nonetheless bear both an "essential nexus" to the interest and a "rough proportionality" to the externalities resulting from the use. ${ }^{27}$ Otherwise, the Court has suggested, the interest advanced by the government is a mere pretext for evading the constitutional obligation to pay compensation that would otherwise result. ${ }^{28}$ Again these foci on effects and pretext serve as examples of AEDs.

AEDs touch all areas of constitutional law. In addition to being ubiquitous, AEDs have a long pedigree. Early examples appear in famous Marshall Court

${ }^{19}$ Professor Denning argues this was the operative proposition in Denning, supra note 6 , at $484-85$.

${ }^{20}$ See, e.g., Minnesota v. Clover Leaf Creamery Co., 449 U.S. 456, 471 (1981).

${ }^{21}$ U.S. CONST. amend. V.

${ }^{22}$ See, e.g., Kelo v. City of New London, 545 U.S. 469, 480 (2005).

${ }^{23}$ See, e.g., First English Evangelical Lutheran Church v. County of Los Angeles, 482 U.S. 304, 315-16 (1987).

${ }^{24}$ See id. at 316 ("[T] he typical taking occurs when the government acts to condemn property in the exercise of its power of eminent domain ....').

${ }^{25}$ Pumpelly v. Green Bay Co., 80 U.S. (13 Wall.) 166, 177-78 (1872).

${ }^{26}$ Lingle v. Chevron, U.S.A., Inc., 544 U.S. 528, 539 (2005).

${ }^{27}$ Dolan v. City of Tigard, 512 U.S. 374, 386, 391 (1994); Nollan v. Cal. Coastal Comm'n, 483 U.S: 825, 837 (1987).

${ }^{28}$ See Nollan, 483 U.S. at 837 ("[T] original purpose of the building restriction converts that purpose to ... the obtaining of an easement ... without payment of compensation."). 
opinions; thus, they are not some modern innovation. In addition to naming AEDs, describing the forms they take, and discussing the characteristics the forms share, this Article also seeks to describe the benefits and costs to constitutional law resulting from AEDs, as well as their implications for doctrinal formation more generally.

We back our claim about the omnipresence and pedigree of AEDs in Part II with examples from a broad swath of constitutional law. In addition, we classify the forms that AEDs take and describe some common characteristics. We argue that AEDs typically - though perhaps not always-supplement rule-like decision rules with decision rules that resemble standards.

Part III discusses the benefits of AEDs and the tradeoffs for doctrine in their widespread use. AEDs are designed to help optimize enforcement of constitutional principles. A major way they do this is by addressing what Professor Sunstein once termed "problems with rules." ${ }^{29}$ This gap-filling function comes at a cost, however. Not only does the addition of AEDs tend to increase doctrinal complexity, but that complexity can also increase decision costs for courts and dilute the benefits of using rules in the first place. There is also the possibility that judicial focus on AEDs, like a focus on decision rules generally, can obscure the principle the rules were meant to enforce, with the result that the doctrinal tail wags the constitutional dog. Nonetheless, despite their shortcomings, AEDs produce a net benefit in constitutional law. We argue, following the literature on risk regulation, that AEDs reflect a "mature position" in the enforcement of constitutional principles.

We discuss the implications of AEDs for constitutional doctrine generally in Part IV. That they seem to be everywhere in constitutional law-and have been so for a long time-suggests that doctrinal complexity should be seen as a feature of our system, and not a bug, because it attempts to ensure form will not trump constitutional substance. If a certain amount of complexity is inevitable, then that suggests one should be skeptical about claims that constitutional law could be rationalized by abandoning what Professor Nagel once called the "formulaic Constitution," in favor of simple, predictable, and easy-to-apply rules. ${ }^{30}$ In fact, the presence of AEDs furnishes strong evidence for Professor Schauer's "convergence hypothesis," which holds that "[w]hen authorised to act in accordance with rules, rule-subjects will tend to convert rules into standards by employing a battery of rule-avoiding devices that serve to soften the hard edges of rules," and vice-versa. ${ }^{31}$

As a final implication, we argue that our highlighting the role AEDs play in constitutional doctrine, for good or ill, is another reason to take doctrine, its formation, and application by courts, seriously. ${ }^{32}$ Meaningful doctrinal study, of

${ }^{29}$ Cass R. Sunstein, Problems with Rules, 83 CALIF. L. REv. 953, 953 (1995).

${ }^{30}$ Robert F. Nagel, The Formulaic Constitution, 84 MiCH. L. REV. 165,165 (1985).

${ }^{31}$ Frederick Schauer, The Convergence of Rules and Standards, 2003 N.Z. L. REV. 303,312 .

${ }^{32}$ See Denning, supra note 10, at 793-96 (describing benefits of the doctrinal turn in constitutional scholarship). 
the type we hope to offer here, can provide better insight into what the Court does, which in turn allows for better normative evaluations of its work and the functions it performs. Additionally, focus on doctrinal design can open avenues of common inquiry among scholars that may differ on the proper interpretative approach to the Constitution. Finally, doctrinal inquiry has practical, as well as academic, value and may help bridge any perceived gaps between the legal academy, on the one hand, and the bench and practicing bar, on the other.

\section{Defining ANd Classifying ANTI-Evasion DOCTRINES}

In this Part, we provide a definition for anti-evasion doctrines, describe the forms that they can take, and then provide examples of those forms from a number of different areas of constitutional law. Not only do we show here their prevalence, but also that AEDs have existed, in some form, as far back as the Marshall Court and continue to be employed today. A common feature of anti-evasion doctrines, we argue, is that they tend to take the form of standards as opposed to rules.

\section{A. Definition}

As we use it in this Article, anti-evasion doctrines (AEDs) are decision rules ${ }^{33}$ developed to fill gaps created by other decision rules, specifically gaps that could enable governmental actors to comply with the form of those earlier-developed rules $^{34}$ while undermining the constitutional principle those rules were intended to implement. AEDs, in part, are decision rules that attempt to optimize enforcement of constitutional principles by preventing their easy circumvention.

\section{B. Taxonomy}

AEDs themselves, moreover, tend to be one of four types of constitutional "tests" that should be familiar to students of constitutional law: pretext tests, proxy tests, purpose tests, or effects tests. ${ }^{35}$ Though each has a slightly different emphasis, and the form each takes varies with the doctrinal context, all have in

${ }^{33}$ As noted earlier, Berman's term "decision rules" can take the form of rules or standards.

${ }^{34}$ We recognize that it may not always be the case that the "other" rules to which AEDs respond were developed prior to the AED itself. As we explain more fully below, however, we view this as the typical pattern revealed in the Court's jurisprudence. See infra notes 157-158 and accompanying text. Moreover, we think that our analysis is the same regardless of whether the AED follows or is created simultaneously with the initial decision rule that it supplements.

${ }^{35}$ With the exception of the "proxy test," we borrow the terminology for the AEDs from Professor Fallon. See FALLON, supra note 6, 77-79 (2001) (describing the following doctrinal tests: (1) "forbidden-content tests," (2) "suspect-content tests," (3) "balancing tests," (4) "non-suspect-content tests," (5) "effects tests," (6) "purpose tests," and (7) "appropriate deliberation tests"). 
common an attempt to prohibit indirect violations of a constitutional command by formal compliance with the decision rule.

As used here, pretext tests ask whether government is, under cover of some permissible goal, actually attempting to regulate in a manner that the Constitution forbids. Proxy tests "regulate on the basis of some characteristic that, while purportedly neutral, has little independent significance and is in reality a proxy for ${ }^{36}$ some characteristic prohibited by the constitutional command or the decision rule. Purpose tests ask whether the law has been "developed or applied for constitutionally illegitimate reasons." explicit content of a statute or policy, but on its effects." ${ }^{38}$ In the rest of this section, we offer several examples in each of these categories. ${ }^{39}$

\section{Pretext Tests}

\section{(a) The Necessary and Proper Clause}

In his capacious interpretation of the Necessary and Proper Clause, ${ }^{40}$ which committed to Congress substantial discretion in choosing means to achieve enumerated ends, Chief Justice John Marshall concluded with a warning:

[S]hould congress, under the pretext of executing its powers, pass laws for the accomplishment of objects not entrusted to the government; it would become the painful duty of this tribunal, should a case requiring such a decision come before it, to say, that such an act was not the law of the land. ${ }^{41}$

Marshall did not specify how the Court was to distinguish pretextual from nonpretextual invocations of the doctrine of implied powers, much less ever strike an implied power down on that ground. Subsequent Courts were equally reticent. ${ }^{42}$

${ }^{36}$ Daniel A. Farber \& Robert E. Hudec, Free Trade and the Regulatory State: A GATT's Eye View of the Dormant Commerce Clause, 47 VAND. L. REV. 1401, 1416 (1994).

${ }^{37}$ FALLON, supra note 6 , at 79 (citation omitted).

${ }^{38}$ Id.

${ }^{39}$ These four categories tend to share characteristics with each other, and they may overlap in certain contexts. Thus, we recognize that some of our following examples might acceptably be viewed in multiple categories or in categories other than those in which we place them.

${ }^{40}$ See McCulloch v. Maryland, 17 U.S. (4 Wheat.) 316, 323-24 (1819).

${ }^{41}$ Id. at 423 .

${ }^{42}$ But see Nat'l Fed'n of Indep. Bus. v. Sebelius, 132 S. Ct. 2566, 2592 (2012) (opinion of Roberts, C.J.) (discussing McCulloch's warning about pretextual invocations; noting that "we have also carried out our responsibility to declare unconstitutional those laws that undermine the structure of government established by the Constitution"). 
Nevertheless, the statement is an early expression of the idea that the Court would not elevate form over substance when it came to core constitutional values.

\section{(b) The Commerce Clause}

Congress did not make much use of the Commerce Clause to authorize federal government power-as opposed to restraining state power over interstate commerce-until the late nineteenth century. ${ }^{43}$ While the Court countenanced considerable exercises of that power in cases like Champion v. Ames ${ }^{44}$ and the Shreveport Rate Cases, ${ }^{45}$ it assumed that there were areas of legislative authority that were reserved to the states exclusively. The Court would thus invalidate exercises of the commerce power on what it deemed pretextual groundsthat is, that Congress's real aim was the invasion of these areas of exclusive state authority:

Take Hammer v. Dagenhart, ${ }^{46}$ for example. Despite cases like Champion, which endorsed broad congressional power to close the channels of interstate commerce to particular goods, ${ }^{47}$ the Court in Hammer invalidated an act prohibiting the shipment in interstate commerce of goods made using child labor. Distinguishing earlier cases on the grounds that they had regulated the transportation of goods that were somehow inherently harmful, ${ }^{48}$ the Court rejected the argument that goods produced using child labor qualified as "harmful.,49

According to the Court, the legislation was not truly aimed at transporting harmful articles in interstate commerce because "[t]he goods shipped are of themselves harmless. ${ }^{, 50}$ Rather, the legislation was more accurately described as an attempt "to standardize the ages at which children may be employed in mining and manufacturing within the States." ${ }^{11}$ Thus, the purported regulation of commerce was really a pretext for regulating health and welfare, areas the Court

${ }^{43}$ See, e.g., JOHN E. NOWAK \& Ronald D. Rotunda, CONSTITUTIONAL LAW 166 (8th ed. 2010).

44188 U.S. 321,363 (1903) (holding that power to "regulate" included power to prohibit mailing of lottery tickets that moved across state lines).

45234 U.S. 342, 351-52 (1914) (concluding that "[w] herever the interstate and intrastate transactions of carriers are so related that the government of the one involves the control of the other, it is Congress, and not the State, that is entitled to prescribe the final and dominant rule"').

46247 U.S. 251 (1918).

${ }^{47}$ Champion, 188 U.S. at 363; see also Hoke v. United States, 227 U.S. 308 (1913) (upholding Mann Act, prohibiting transportation of women in interstate commerce for immoral purposes); Hippolite Egg Co. v. United States, 220 U.S. 45 (1911) (upholding Pure Food and Drug Act's prohibition of shipment in interstate commerce of impure or adulterated foods).

${ }^{48}$ Hammer, 247 U.S. at 271.

${ }^{49}$ Id. at 272 .

${ }^{50} \mathrm{Id}$.

${ }^{51} I d$. 
assumed were left to the exclusive control of the states. "The grant of authority over a purely federal matter was not intended to destroy the local power always existing and carefully reserved to the States in the Tenth Amendment to the Constitution," the Court noted, adding that "[p]olice regulations relating to the internal trade and affairs of the States have been uniformly recognized as within such control.",53

The Court adopted a similar position regarding congressional attempts to regulate the coal industry - one of Franklin Roosevelt's signature New Deal programs-in Carter v. Carter Coal Co. ${ }^{54}$ In his opinion, Justice Sutherland distinguished between "commerce," on the one hand, and activities like mining that were "local" and "antecedent" to commerce, on the other. ${ }^{55}$ The latter, he maintained, remained the exclusive province of the states.

Much stress is put upon the evils which come from the struggle between employers and employees over the matter of wages, working conditions, the right of collective bargaining, etc., and the resulting strikes, curtailment and irregularity of production and effect on prices; and it is insisted that interstate commerce is greatly affected thereby. But, in addition to what has just been said, the conclusive answer is that the evils are all local evils over which the federal government has no legislative control. The relation of employer and employee is a local relation. ${ }^{56}$

As in Hammer, the Court concluded that the invocation of the commerce power was merely pretextual; the real aim was to regulate those local matters that, in the Court's opinion, the Constitution intended to leave to the states. ${ }^{57}$ The Court explained that Congress could regulate matters that "directly" affected interstate commerce; the multitude of other things that affected interstate commerce only "indirectly" were beyond congressional reach. ${ }^{58}$ The Court further explained that " $[t]$ he word 'direct' implies that the activity or condition invoked or blamed shall operate proximately-not mediately, remotely, or collaterally-to produce the effect. It connotes the absence of an efficient intervening agency or condition." 59 The Court also stressed that "the extent of the effect bears no logical relation to its character. The distinction between a direct and an indirect effect turns, not upon

${ }^{52}$ Id. at 273-74 ("The grant of power to Congress over the subject of interstate commerce was to enable it to regulate such commerce, and not to give it authority to control the States in their exercise of the police power over local trade and manufacture.").

${ }^{53} \mathrm{Id}$. at 274.

${ }^{54} 298$ U.S. 238 (1936).

${ }^{55} \mathrm{Id}$. at $303-04$.

${ }^{56} I d$. at 308 .

${ }^{57}$ Id.

${ }^{58} I d$. at $307-08$.

${ }^{59}$ Id. 
the magnitude of either the cause or the effect, but entirely upon the manner in which the effect has been brought about." ${ }^{, 60}$

\section{(c) Conditional Spending}

In South Dakota v. Dole ${ }^{61}$ the Court held that conditions on spending were permissible - even where Congress lacked authority to impose them directly-if (1) spending was for the "general welfare," (2) the condition was clear and unambiguous, (3) the condition was related to a federal interest in a particular program, and (4) the condition did not otherwise violate another part of the Constitution. ${ }^{62}$ In addition, however, the Court suggested that, at some point, linking conditions to spending could cross a line into "coercion" that deprived states of a real choice. ${ }^{63}$ This "coercion" limit echoed prior decisions in cases like United States v. Butler ${ }^{64}$ in which the Court invalidated an earlier conditional spending program on the ground that it was an indirect attempt by Congress to regulate agriculture and production that were the exclusive reserves of the states. ${ }^{65}$ While the Dole Court did not indicate under what circumstances a spending condition might trigger this limitation ${ }^{66}$ in 2012 seven members of the Court held that the Affordable Care Act went too far in putting to states the "choice" between

${ }^{60} \mathrm{Id}$. at 308 . The Court would, of course, abandon this later. Current law holds that the regulation of even local economic subject matters can be regulated if, in the aggregate, they would substantially affect interstate commerce, even if individual instances of the class of activities regulated would, by itself, not have that effect. See, e.g., Gonzales v. Raich, 545 U.S. 1, 32-33 (2005) (upholding application of the federal Controlled Substances Act to local, noncommercial possession and use of marijuana for medical purposes as authorized by state law). Five Justices in National Federation of Independent Business v. Sebelius, 132 S. Ct. 2566 (2012), recently opined that Gonzales did not enable Congress to reach inactivity alleged to substantially affect interstate commerce. $I d$. at 2587 (opinion of Roberts, C.J.) ("Allowing Congress to justify federal regulation by pointing to the effect of inaction on commerce would bring countless decisions an individual could potentially make within the scope of federal regulation, and . . . empower Congress to make those decisions for him."); id. at 2648 (joint dissent) ("[I]f every person comes within the Commerce Clause power of Congress to regulate by the simple reason that he will one day engage in commerce, the idea of a limited Government power is at an end."). For a recent argument asserting that the Court should revive pretext analysis for congressional exercises of its commerce power, see Gil Seinfeld, The Possibility of Pretext Analysis in Commerce Clause Adjudication, 78 Notre DAME L. REV. 1251 (2003).

${ }^{61} 483$ U.S. 203 (1987).

${ }^{62}$ Id. at $207-08$.

${ }^{63} \mathrm{Id}$. at 208.

${ }^{64} 297$ U.S. 1 (1936).

${ }^{65} \mathrm{Id}$. at $70-71$.

${ }^{66}$ For scholars' attempts to articulate limits to the spending power, see, for example, Lynn A. Baker, Conditional Federal Spending after Lopez, 95 ColuM. L. REV. 1911, 1921-23 (1995); and Richard W. Garnett, The New Federalism, the Spending Power, and Federal Criminal Law, 89 CORNELL L. REV. 1, 23-33 (2003). 
a radical (and expensive) expansion of Medicaid and the loss of all Medicaid funds. ${ }^{67}$ Writing for himself-joined by Justice Breyer and Justice Kagan-the Chief Justice wrote that unlike past cases such as Dole, "the financial 'inducement' Congress has chosen is much more than 'relatively mild encouragement'-it is a gun to the head." ${ }^{, 68}$ As the joint dissent of Justices Scalia, Kennedy, Thomas, and Alito put it, "[I]f States really have no choice other than to accept the package, the offer is coercive, and the conditions cannot be sustained under the spending power. ... [T] heoretical voluntariness is not enough." ${ }^{, 69}$ Thus, at a minimum, a solid majority has defined "coercive" federal spending conditions to be those that leave states no realistic alternative than to accept them.

\section{(d) The Takings Clause and "Public Use"}

In its controversial decision in Kelo $v$. City of New London, ${ }^{70}$ the Court reaffirmed that to satisfy the Fifth Amendment's "public use" requirement, a government condemnation of private property must serve some public purpose. ${ }^{71}$ Additionally, the Court noted that the term "public purpose" was to receive a broad construction, reflecting the deference owed to legislative determinations on the issue. ${ }^{72}$ Even so, the Court suggested that such deference was not the same as outright abdication of the issue to the legislative branches. After noting that the City would be prohibited from condemning property for the overt purpose of conferring purely private benefits, the Court went on to say that the City would also be prohibited from taking property "under the mere pretext of a public purpose, when its actual purpose was to bestow a private benefit." ${ }^{, 73}$ Justice Kennedy, who provided the crucial fifth vote in Kelo, echoed this admonition in his concurrence: "[T]ransfers intended to confer benefits on particular, favored private entities, and with only incidental or pretextual public benefits, are forbidden by the Public Use Clause." 74

\section{Proxy Tests}

\section{(a) The Tonnage Clause}

Article I, section 10 of the Constitution prohibits states from "lay[ing] any Duty of Tonnage" without congressional consent. ${ }^{75}$ Duties of tonnage are those

${ }^{67}$ Nat'l Fed'n of Indep. Bus. v. Sebelius, 132 S. Ct. 2566, 2604 (plurality opinion) (calling the penalty a "gun to the head").

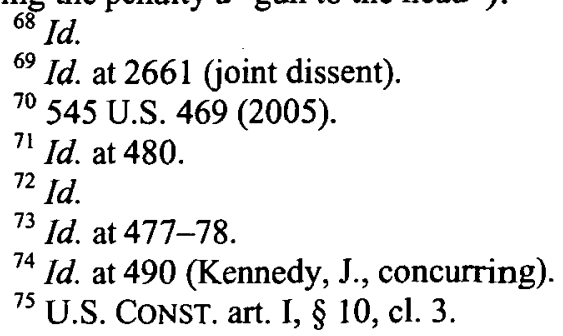


imposed on the carrying capacity of ships upon entry or exit from a port. ${ }^{76}$ However, the Court has invalidated certain fees not computed on the basis of carrying capacity as violations of the Tonnage Clause. In Southern Steamship Co. v. Portwardens, ${ }^{77}$ for example, Louisiana imposed a flat fee for the privilege of entering the Port of New Orleans. Invalidating the fee, the Court observed:

We think, also, that the tax . . . is, in the fair sense of the word, a duty on tonnage. In the most obvious and general sense it is true, those words describe a duty proportioned to the tonnage of the vessel; a certain rate on each ton. But it seems plain that, taken in this restricted sense, the [Tonnage Clause] would not fully accomplish its intent . . . . It was not only a pro rata tax which was prohibited, but any duty on the ship, whether a fixed sum upon its whole tonnage, or a sum to be ascertained by comparing the amount of tonnage with the rate of duty. ${ }^{78}$

The approach of the Southern Steamship Court was recently affirmed in Polar Tankers, Inc. v. Valdez, ${ }^{79}$ in which the Court struck down a state ad valorem tax on large vessels docking at Alaska's ports. Though by its terms it applied to all vessels exceeding ninety-five feet in length or that take on cargo or engage in business worth more than $\$ 1$ million, in practical effect, "[t] $]$ he ordinance applies almost exclusively to oil tankers." is closely correlated with cargo capacity." heart of what the Tonnage Clause forbids," the Court invalidated the tax. ${ }^{82}$

\section{(b) The Privileges and Immunities Clause of Article IV}

Article IV, § 2 guarantees "[t]he Citizens of each State" the "Privileges and Immunities of Citizens in the several States." like the right to compete for business or to pursue a common calling, states cannot

${ }^{76}$ BORIS I. BITTKER WITH THE COLLABORATION OF BRANNON P. DENNING, BITTKER ON THE REGULATION OF INTERSTATE AND FOREIGN COMMERCE $\S .12 .10$, at 12-38 to -39 (1999) (distinguishing tonnage duties from "fees assessed for specific services, such as towage ... or pilotage").

7773 U.S. (6 Wall.) 31 (1867).

${ }^{78} \mathrm{Id}$. at $34-35$.

${ }^{79} 557$ U.S. 1 (2009).

${ }^{80} \mathrm{Id}$. at 10.

${ }^{81} 1 d$.

${ }^{82} \mathrm{Id}$.

${ }^{83}$ U.S. CoNST. art. IV, $\S 2$, cl. 1.

${ }^{84}$ See Baldwin v. Fish \& Game Comm'n, 436 U.S. 371, 388 (1978) (finding that hunting is not fundamental right; state charging out-of-state residents more for elk hunting license did not violate the Privileges and Immunities Clause). 
treat out-of-state citizens worse than in-state citizens. ${ }^{85}$ If state or local measures do so, the state must prove (1) a substantial reason for the discrimination, and (2) that the discrimination bears a substantial relationship to the reason for discriminating in the first place. ${ }^{86}$ Some commentators have argued that the Privileges and Immunities Clause might not apply unless there is explicit discrimination. ${ }^{87}$

In Hillside Dairy, Inc. $v$. Lyons,${ }^{88}$ however, the Court held that discrimination on the basis of state citizenship or state residence were not the sole bases for maintaining a Privileges and Immunities Clause challenge. ${ }^{89}$ Out-of-state milk producers challenged amendments to California's milk pricing scheme, alleging, among other things, that the amendments violated the Privileges and Immunities Clause. ${ }^{90}$ The lower court rejected the claim, holding that the producers had no standing to raise the claim because the California law did not classify on the basis of either state citizenship or state residency. ${ }^{91}$ In an earlier case, Chalker v. Birmingham \& Northwestern Railway Co., ${ }^{92}$ the Supreme Court held that a Tennessee tax imposed on persons having their principal place of business outside the state violated the Clause. ${ }^{93}$ Without ruling on the merits of the claim, the Hillside Dairy Court reaffirmed Chalker:

Whether Chalker should be interpreted as merely applying the Clause to classifications that are but proxies for differential treatment against outof-state residents, or as prohibiting any classification with the practical effect of discriminating against such residents, is a matter we need not decide at this stage of these cases. Under either interpretation, we agree with petitioners that the absence of an express statement in the California laws and regulations identifying out-of-state citizenship as a basis for disparate treatment is not a sufficient basis for rejecting this claim. ${ }^{94}$

${ }^{85}$ See, e.g., Toomer v. Witsell, 334 U.S. 385, 399 (1948) (finding imposition of a higher license fee for out-of-state shrimpers violates Privileges and Immunities Clause).

${ }^{86} \mathrm{Id}$. at 396.

${ }^{87}$ See Brannon P. Denning, Why the Privileges and Immunities Clause of Article IV Cannot Replace the Dormant Commerce Clause Doctrine, 88 MINN. L. REv. 384, 390-91 $\&$ n.22 (2003) (making the argument and citing sources sharing that assumption).

88 539 U.S. 59 (2003).

${ }^{89} \mathrm{Id}$. at 67.

${ }^{90} \mathrm{Id}$. at $63-64$.

${ }^{91} \mathrm{Id}$. at 67.

92249 U.S. 522 (1919).

${ }^{93}$ Id. at 527.

${ }^{94}$ Hillside Dairy, 539 U.S. at 67. 


\section{(c) Land Use Exactions}

In Nollan v. California Coastal Commission ${ }^{95}$ and Dolan v. City of Tigard, ${ }^{96}$ the Court held that land use exactions would be deemed compensable takings where they did not bear an "essential nexus" to a legitimate state interest ${ }^{97}$ and a "rough proportionality" to the putative impact the proposed land use would have on that interest. ${ }^{98}$ This test operates in a manner similar to a proxy test by looking to see whether the government is imposing conditions on the use of land as a substitute for appropriating private property via eminent domain. The facts of Nollan prove illustrative. In that case, the government conditioned approval of a development permit on the applicants granting a lateral easement across their parcel so as to connect two public beaches that lay on either side. ${ }^{99}$ The government justified this condition on the grounds that the new house would obstruct the beaches from view of the road, impairing the public's "visual access" to the beaches. ${ }^{100}$ The Court, however, held that the condition amounted to an unconstitutional taking because it bore no connection to the public harmimpairment of "visual access"- that the development supposedly was going to cause. $^{101}$ Absent such a connection, the condition was simply an attempt to appropriate the easements in a manner that would avoid the government's having to pay for them. ${ }^{102}$

\section{(d) State Action Doctrine}

Despite its reputation as a "conceptual disaster area,"103 the Court has continued to enforce the state action doctrine, which limits the reach of the Fourteenth and Fifteenth Amendments to "state actors." 104 However, the Court has pierced the private actor veil, so to speak, on occasions where private entities exercise some "quintessential public function." In Marsh v. Alabama, ${ }^{105}$ for

${ }^{95} 483$ U.S. 825 (1987).

${ }^{96} 512$ U.S. 374 (1994).

${ }^{97}$ Nollan, 483 U.S. at 837.

${ }^{98}$ Dolan, 512 U.S. at $386,391$.

${ }^{99}$ Nollan, 483 U.S. at 828 .

${ }^{100} \mathrm{Id}$. at 838 .

${ }^{101}$ Id. at $838-39$.

${ }^{102} I d$. at 837 ("[T] he lack of nexus between the condition and the original purpose of the building restriction converts that purpose to something other than what it was. The purpose then becomes, quite simply, the obtaining of an easement . . . without payment of compensation.").

${ }^{103}$ Charles L. Black, Jr., The Supreme Court, 1966 Term-Foreword: "State Action," Equal Protection, and California's Proposition 14, 81 HARV. L. REV. 69, 95 (1967).

${ }^{104}$ See, e.g., United States v. Morrison, 529 U.S. 598, 622 (2000) (invalidating civil suit provision of the Violence Against Women Act); The Civil Rights Cases, 109 U.S. 3, 11 (1883) ("It is State action of a particular character that is prohibited. Individual invasion of individual rights is not the subject-matter of the [Fourteenth] [A]mendment.").

${ }^{105} 326$ U.S. 501 (1946). 
example, the Court found that a company-owned town was a state actor because it furnished all the services and performed the usual functions of a municipality. ${ }^{106}$ As a state actor, it was subject to the First Amendment and thus unable to stop a person from distributing literature on its streets. ${ }^{107}$

Another exception to the state action doctrine was created in Burton $v$. Wilmington Parking Authority, ${ }^{108}$ where the Court held that a private coffee shop that discriminated against African-Americans was a state actor because of its location in a public parking facility and the terms of its lease with the public authority that ran that facility. ${ }^{109}$ Based on the facts, the Court concluded that

[t]he State has so far insinuated itself into a position of interdependence with [the coffee shop] that it must be recognized as a joint participant in the challenged activity, which, on that account, cannot be considered to have been so "purely private" as to fall without the scope of the Fourteenth Amendment. ${ }^{10}$

The Court recently applied its "pervasive entwinement" exception to hold that a state high school athletic association was a state actor where its members included most of the public schools in the state, its board included state officials as ex officio members, and its employees were state employees eligible for participation in the state retirement program. ${ }^{11}$

\section{Purpose Tests and Effects Tests}

\section{(a) Free Speech}

A core distinction in First Amendment doctrine is that between content-based and content-neutral speech regulations. ${ }^{112}$ Content-based speech restrictions are subject to strict scrutiny, while content-neutral restrictions need to satisfy the less demanding intermediate scrutiny. ${ }^{113}$ However, the Court's application of intermediate scrutiny to content-neutral regulations includes an inquiry into whether "the governmental interest is unrelated to the suppression of free expression." 114 If "the government has adopted a regulation of speech because of

\footnotetext{
${ }^{106}$ Id. at $507-08$.

${ }^{107} \mathrm{Id}$. at $508-10$.

${ }^{108} 365$ U.S. 715 (1961).

${ }^{109}$ Id. at $723-24$.

${ }^{110} \mathrm{Id}$. at 725 .
} 298 (2001).

${ }^{111}$ Brentwood Acad. v. Tenn. Secondary Sch. Athletic Ass'n, 531 U.S. 288,

112 See ERWIN Chemerinsky, Constitutional LaW: Principles and Policies 932 33 (3d ed. 2006).

${ }^{113} I d$. at 933.

${ }^{114}$ United States v. O’Brien, 391 U.S. 367, 377 (1968); see also Elena Kagan, Private Speech, Public Purpose: The Role of Governmental Motive in First Amendment Doctrine, 
disagreement with the message it conveys," then the regulation will be subject to strict scrutiny despite its facial content-neutrality. ${ }^{115}$

\section{(b) Free Exercise}

After Employment Division v. Smith ${ }^{116}$ generally applicable regulations that incidentally affect an individual's free exercise of religion do not violate the Free Exercise Clause. ${ }^{117}$ However, the Court has held that facially neutral regulations that, in their effects, target a particular religion or set of religious practices are subject to strict scrutiny. ${ }^{118}$ A plurality of the Court has similarly held that "ordinances . . . enacted 'because of,' not merely 'in spite of,' their suppression of [a] religious practice" are similarly subjected to strict scrutiny despite their apparent facial neutrality. ${ }^{119}$

\section{(c) The Dormant Commerce Clause Doctrine}

The dormant Commerce Clause doctrine (DCCD) limits the ability of state and local governments to discriminate against or otherwise impermissibly burden interstate commerce. ${ }^{120} \mathrm{~A}$ state or local law discriminating against interstate commerce on its face ${ }^{121}$ is subject to a "virtually per se rule of illegitimacy," requiring the government to demonstrate that (1) the law is aimed at a legitimatewhich is to say non-protectionist-end, and (2) that no less-discriminatory means are available to effectuate that end. ${ }^{122}$ Nondiscriminatory but burdensome laws are subject to a more lenient balancing test requiring the challenger to prove that the burdens on interstate commerce clearly exceed the local benefits claimed for the law. ${ }^{123}$

63 U. CHI. L. REV. 413 (1996) (discussing the application of First Amendment law as a tool to discover and invalidate government actions that are done with improper motives).

${ }^{115}$ Ward v. Rock Against Racism, 491 U.S. 781, 791 (1989).

${ }^{116} 494$ U.S. 872 (1990).

${ }^{117}$ Id. at 878; U.S. CONST. amend. I ("Congress shall make no law ... prohibiting the free exercise [of religion] ....").

${ }^{118}$ Church of the Lukumi Babalu Aye, Inc. v. Hialeah, 508 U.S. 520, 533 (1993).

${ }^{119}$ Id. at $540-41$.

${ }^{120}$ See generally Denning, supra note 6, at 447-48 (surveying the dormant Commerce Clause doctrine).

${ }^{121}$ Facially discriminatory laws are not subject to this scrutiny if the state or local government is either acting as a "market participant" or is discriminating in favor of a "public entity." See United Haulers Ass'n, Inc. v. Oneida-Herkimer Solid Waste Mgmt. Auth., 550 U.S. 330, 362-63 (2007); Reeves, Inc. v. Stake, 447 U.S. 429, 442-46 (1980) (upholding "locals-first" rule by state-owned cement plant faced with a glut of orders brought on by cement shortage). The Court has also assumed, without so holding, that cash subsidies may be offered on a discriminatory basis. See West Lynn Creamery v. Healy, 512 U.S. 186,199 n.15 (1994).

${ }^{122}$ See, e.g., Philadelphia v. New Jersey, 437 U.S. 617, 626-27 (1978).

${ }^{123}$ Pike v. Bruce Church, Inc., 397 U.S. 137, 142 (1970). 
But the Court has applied heightened scrutiny even to facially neutral laws that were shown either to have been passed with a discriminatory purpose ${ }^{124}$ or result in discriminatory effects. ${ }^{125}$ Among the effects the Court has held to trigger this heightened scrutiny are (1) effectively barring the import of out-of-state goods or barring their sale once imported, (2) raising the costs of doing business in a state for out-of-state but not in-state competitors, (3) stripping competitive advantages from out-of-state businesses, or (4) leveling the playing field in favor of in-state competitors. $^{126}$ The Court has also invalidated a tax-and-subsidy scheme that resulted in only out-of-state businesses paying a particular tax (because in-state businesses received subsidies paid out of revenues gleaned by a facially neutral tax). ${ }^{127}$

Additionally, even truly facially neutral statutes, untainted by discriminatory purpose and lacking discriminatory effects, may nevertheless be invalidated if, in the opinion of the Court, the burdensome effects on interstate commerce "clearly exceed" the local benefits claimed for the law. ${ }^{128}$

\section{(d) Abortion}

The plurality opinion in Planned Parenthood of Southeastern Pennsylvania $v$. Casey ${ }^{129}$ discarded Roe v. Wade's trimester framework, substituting "viability" as the point at which the state may bar abortions altogether. ${ }^{130}$ For previability abortions, the Court - again in contrast to Roe-found that the state had an interest in protecting potential life and that it was entitled to regulate abortions to further that interest. ${ }^{131}$

To distinguish between permissible and impermissible regulation of previability abortions, the plurality also articulated the "undue burden" test: "[A] law which serves a valid purpose, one not designed to strike at the right itself," but which "has the incidental effect of making it more difficult or expensive to procure an abortion cannot be enough to invalidate it." "132 A "finding of undue burden," the Court further explained, "is a shorthand for the conclusion that a state regulation has the purpose or effect of placing a substantial obstacle in the path of a woman seeking an abortion of a nonviable fetus."133

\footnotetext{
${ }^{124}$ Bacchus Imports, Ltd. v. Dias, 468 U.S. 263, 270 (1984).

${ }^{125}$ Hunt v. Wash. State Apple Advertisers Comm'n, 432 U.S. 333, 350-53 (1977).

${ }^{126} \mathrm{Id}$. at $350-52$.

${ }^{127}$ West Lynn Creamery v. Healy, 512 U.S. 186, 194-95 (1994).

${ }^{128}$ Pike, 397 U.S. at 142.

${ }^{129} 505$ U.S. 833 (1992) (plurality opinion).

${ }^{130} \mathrm{Id}$. at 846.

${ }^{131} \mathrm{Id}$. at 872 .

${ }^{132}$ Id. at 874 (emphasis added).

${ }^{133}$ Id. at 877 (emphasis added).
} 


\section{(e) Race Discrimination}

Though the Court has held that disparate impact is not sufficient to maintain a race discrimination claim under the Fourteenth Amendment, ${ }^{134}$ intent to discriminate may be found other than on the face of the statute. In Village of Arlington Heights v. Metropolitan Housing Development Corp.,${ }^{135}$ the Court acknowledged the difficulty that its decision in Washington $v$. Davis placed on plaintiffs attempting to prove that a facially neutral law was, in fact, motivated by a discriminatory intent. "Determining whether invidious discriminatory purpose was a motivating factor," the Court wrote, "demands a sensitive inquiry into such circumstantial and direct evidence of intent as may be available.",136

While not "purporting to be exhaustive," the Court suggested several "subjects of proper inquiry in determining whether racially discriminatory intent existed." 137 These included: (1) "whether [the official action] "bears more heavily on one race than another"'; (2) "[t]he historical background of the decision . . ., particularly if it reveals a series of official actions taken for invidious purposes"; (3) "[t]he specific sequence of events leading up to the challenged decision"; (4) "[d]epartures from the normal procedural sequence" of decisionmaking; (5) "[s]ubstantive departures . . . , particularly if the factors usually considered important by the decisionmaker strongly favor a decision contrary to the one reached"; and (6) "[t]he legislative or administrative history . . ., especially where there are contemporary statements by members of the decisionmaking body, minutes of its meetings, or reports." 138

Plaintiffs can also show that a facially neutral law is enforced in a discriminatory manner. When, in a discriminatory manner, a city enforced an ordinance requiring that laundries be located in brick or stone buildings only against Chinese-owned laundries, the Court reversed a conviction for violating the ordinance. ${ }^{139}$ The Court concluded that the evidence demonstrated the authorities were applying the ordinance "with a mind so unequal and oppressive as to amount to a practical denial by the State of . . . equal protection of the laws." 140

\section{(f) The Fifteenth Amendment}

The Fifteenth Amendment prohibits abridging voting rights by states or the federal government "on account of race, color, or previous condition of servitude." "141 Here too, though, "laws that are facially neutral will be declared unconstitutional when they were motivated by a discriminatory purpose and have a

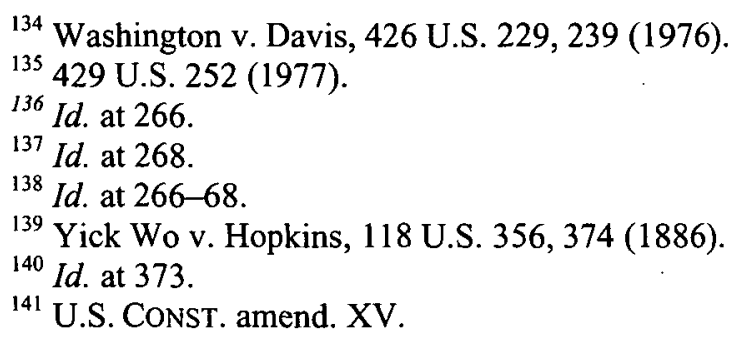


discriminatory impact." ${ }^{142}$ In Guinn v. United States, ${ }^{143}$ for example, the Court invalidated a literacy test that exempted voters and their descendants who could vote in $1865 .{ }^{144}$ The motive behind this so-called "grandfather clause" was to exclude black voters. ${ }^{145}$ And in Gomillion v. Lightfoot, ${ }^{146}$ the Court concluded that the redrawing of the boundaries of Tuskegee, Alabama, was done with the intent to exclude nearly all African-Americans from its boundaries. ${ }^{147}$ Because of the improper motive, the Court concluded the city's actions, though neutral on their face, violated the rights to suffrage guaranteed by the Fifteenth Amendment. ${ }^{148}$

\section{(g) Regulatory Takings}

As noted in the Introduction, the Court's regulatory-takings jurisprudence largely operates as an anti-evasion measure to prevent the government from skirting its obligation to compensate owners for the taking of their property. The complex series of decision rules that make up this jurisprudence seem, at bottom, to take the form of effects tests. First, consider the rule articulated in Loretto v. Manhattan Teleprompter CATV Corp. ${ }^{149}$ where the Court held that a regulatory action that results in a permanent physical occupation of property is a taking per se. ${ }^{150}$ The Court explained this rule first by focusing on the consequences of such an occupation, which it viewed as "effectively destroy[ing] each" of the traditional rights of a property owner to possess, use, transfer, and exclude. ${ }^{151}$ The Court also has held that constructive physical occupations of private property are to be treated as actual occupations inasmuch as "[t]here is no material difference" between the two types. ${ }^{152}$ Further, a regulation can be tantamount to permanent physical occupation if it deprives the owner of "all economically beneficial or productive use of land" 153 because, in such circumstances, the regulation is, "from the landowner's point of view, the equivalent of a physical appropriation." ${ }^{.154}$ Echoing the effects test characteristics of these holdings, the Court recently explained that its takings decisions focus "directly upon the severity of the burden that

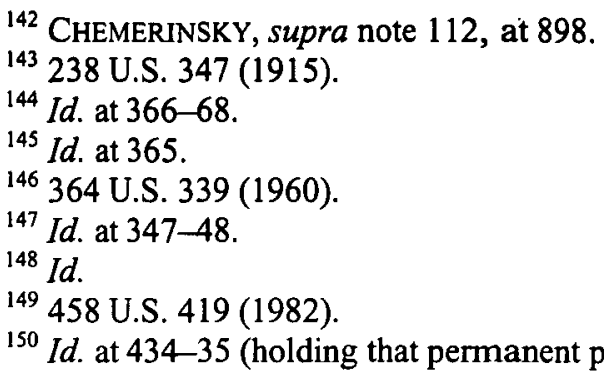
to whether the action achieves an important publi impact on the owner"); see also id. at 438 n.16 (making clear that the size of the occupation is irrelevant).

\footnotetext{
${ }^{151} I d$. at $435-36$.

${ }^{152}$ See, e.g., United States v. Causby, 328 U.S. 256, 262 (1946).

${ }^{153}$ Lucas v. S.C. Coastal Council, 505 U.S. 1003, 1015 (1992).

${ }^{154}$ Id. at 1017.
} 
government imposes upon private property rights"155 with the goal of "identify[ing] regulatory. actions that are functionally equivalent to the classic taking in which government directly appropriates private property or ousts the owner from his domain."156

\section{Common Characteristics of Anti-Evasion Doctrines}

In these numerous and varied areas of constitutional doctrine, a pattern emerges. The Court begins with a decision rule to enforce a particular constitutional principle. That decision rule, in turn, is bolstered or backstopped by an AED intended to prevent circumvention of the constitutional command by formal compliance with the decision rule itself-that is, compliance that nevertheless permits avoidance of the principle the initial decision rule was designed to implement. Moreover, AEDs tend to crop up when that initial decision rule takes the form of a rule. The AEDs, by contrast, tend to be formulated as standards rather than rules.

We use this general pattern to describe AEDs because it represents what we see in many of the Court's own decisions - that is, early opinions that implement a constitutional principle with a rule-like decision rule, followed by subsequent decisions that bolster that rule with more standard-like decision rules. ${ }^{157}$ But we do not mean to suggest that this pattern necessarily holds in every context in which the Court has employed AEDs. It may be that there are AEDs that take a more rule-like form to backstop decision rules that themselves take the form of standards. ${ }^{158}$ Additionally, there are instances where AEDs, rather than following after a primary decision rule, are instead pronounced simultaneously with it. ${ }^{159}$ For analytical purposes, however, these distinctions do not make much of a difference. Overall, the ebb and flow of constitutional adjudication tends to consist of the Court's establishment of a primary, typically rule-like decision rule that is backstopped by a typically standard-like AED (whether created subsequently or simultaneously). Moreover, by describing the AED as a "backstop," we do not intend to minimize the importance of the backstopping function or somehow suggest that the AED enjoys a subordinate place in the relationship-any more than a good catcher in baseball is subordinate to a pitcher. Rather, as we explain

${ }^{155}$ Lingle v. Chevron, U.S.A., Inc., 544 U.S. 528, 539 (2005).

${ }^{156} \mathrm{Id}$.

${ }^{157}$ See, e.g., infra notes 359-362 (describing the Court's takings jurisprudence).

${ }^{158}$ See, e.g., Miranda v. Arizona, 384 U.S. 436, $444-45$ (1966) (employing rule-like requirements to backstop basic norm that statements made by criminal defendant be voluntary).

${ }^{159}$ See, e.g., South Dakota v. Dole, 483 U.S. 203, 207-08, 211 (1987) (pronouncing AED in same opinion as primary decision rule). It seems that the "activity/inactivity" distinction in National Federation of Independent Business is another such rule-like AED intended to backstop the more standard-like "substantial effects" test. See Nat'l Fed'n of Indep. Bus. v. Sebelius, 132 S. Ct. 2566, 2589-90, 2593 (opinion of Roberts, C.J.); id. at 2649 (joint dissent). 
more fully below, this pattern demonstrates that the overall doctrine of a constitutional area will employ both rules and standards in a converging, symbiotic relationship - with the rules designed to address the earlier and easier cases, and the standard-like AEDs designed to deal with those cases that are more difficult.

The interaction between initial decision rules and AEDs thus implicates the rules-versus-standards debate, and it also has implications for doctrinal formation generally. In this section, we situate our discussion of AEDs in that rules/standards debate and illustrate our argument with some examples. The next part describes in detail the benefits and tradeoffs accompanying these reinforcing sets of decision rules.

The rules-versus-standards distinction is a familiar one in legal scholarship ${ }^{160}$ and in constitutional law. ${ }^{161}$ The literature "commonly emphasize[s] the distinction between whether the law is given content ex ante or ex post." ${ }^{162}$ Rules seek to give content to law ex ante, while standards permit it to be given after the fact. ${ }^{163}$ As Professor Sullivan explained, "Rules aim to confine the decisionmaker to facts, leaving irreducibly arbitrary and subjective value choices to be worked out elsewhere." ${ }^{164}$ The classic example is that of a law limiting speeds to $X$ miles per hour. Standards, on the other hand, "allow for the decrease of errors of under- and over-inclusiveness by giving the decisionmaker more discretion than do rules." 165 Instead of expressing a limit as $X$ miles per hour, a speed limit formulated as a standard might read, "Drive at a reasonable speed given road conditions." Here, when we talk about standards, we adopt this general description-that standards give decisionmakers discretion to make law ex post and in light of the facts of individual cases.

${ }^{160}$ The literature on rules versus standards is voluminous. For succinct introductions to the debate, see WARD FARNSWORTH, THE LEgAL ANALYST: A TOOLKIT FOR THINKING ABOUT THE LAW 164-68 (2007); and FREDERICK SCHAUER, THINKING LiKE A LAWYER: A NEW InTROduction to LEgal Reasoning 189-200 (2009). Canonical articles include Louis Kaplow, Rules Versus Standards: An Economic Analysis, 42 DUKE L.J. 557 (1992), Antonin Scalia, The Rule of Law as a Law of Rules, 56 U. CHI. L. REV. 1175 (1989), Pierre Schlag, Rules and Standards, 33 UCLA L. REv. 379 (1985), Sullivan, supra note 15, and Sunstein, supra note 29. For an interesting account of how judges choose between rules and standards, see Scott A. Baker \& Pauline Kim, A Dynamic Model of Doctrinal Choice (Wash. Univ. in St. Louis Legal Studies Research Paper No. 12-01-04, 2012), available at http://ssrn.com/abstract=1983446/; Andrew B. Coan, Judicial Capacity and the Substance of Constitutional Law, 122 YALE L.J. 422 (2012), available at http://papers.ssrn.com/sol3/ papers.cfm?abstract_id=2000735/; and Frank Cross et al., $A$ Positive Political Theory of Rules and Standards, 2012 U. ILL. L. REV. 1.

${ }^{161}$ See, e.g., Sullivan, supra note 15.

162 Kaplow, supra note 160, at 559 (citation omitted).

${ }^{163}$ Id. at 601 ("A legal command is defined here to be rule-like to the extent that greater effort has been expended $e x$ ante, rather than requiring such effort to be made ex post.").

${ }^{164}$ Sullivan, supra note 15 , at 58 (citation omitted).

${ }^{165}$ Id. at 58-59 (citation omitted). 
In our account, AEDs exist to bolster the rule and, by extension, the constitutional principle (Berman's "constitutional operative proposition") that the initial decision rule was intended to implement. In some cases, the initial decision rule closely tracks the language of the Constitution itself. For example, the Court has interpreted the prohibition on tonnage duties to, well, bar states from laying tonnage duties on vessels. ${ }^{166}$ Similarly, the state action doctrine is rooted in the address of the Fourteenth Amendment to states, ${ }^{167}$ in contrast to the Thirteenth Amendment, which contained no such limitation. ${ }^{168}$

But in both cases, standard-like AEDs supplement those rules to enforce the substance of the constitutional principle in the face of attempts at formal compliance that, if tolerated, would effectively gut the prohibitions. Therefore, any tax or levy that is directly or indirectly based on the carrying capacity of a ship (a levy on the total value of the cargo, for instance), whatever it may be called, violates the Tonnage Clause. ${ }^{169}$ Similarly, not all private actors can escape the obligations of the Fourteenth Amendment. Private actors "pervasively entwined" with state actors or who perform all the tasks of a state actor will themselves be considered state actors, despite their putative private status. ${ }^{170}$

Note, too, how these formula_-"pervasively entwined" and "closely correlates"- do not establish rigid criteria that determine either how pervasive the entwinement need be or how closely to cargo capacity a tax needs to correlate. These are determinations that courts make after the fact, in light of the particular facts before them. They are standards, in other words.

The Takings Clause presents another example of the pattern we describe. First, as noted above, the Court has made clear that it will ordinarily defer to legislative judgments that a particular taking is "for public use." stated in Kelo that pretextual public use takings that in actuality transferred land between private owners for private purposes would not be countenanced, even as the Court left rather vague what facts would support a finding of pretext. ${ }^{172}$ In addition, the Court's entire regulatory takings jurisprudence serves as an elaborate body of AEDs, preventing government from simply using its regulatory power to achieve indirectly what could not be accomplished through outright appropriation-that is, an uncompensated taking. ${ }^{173}$ Further, and it is the subject of much complaint from members of the Court and commentators, the regulatory takings doctrine depends largely on standards, from Justice Holmes's "too far"

${ }^{166}$ See Steamship Co. v. Portwardens, 73 U.S. (6 Wall.) 31, 32, 34-35 (1867).

${ }^{167}$ See U.S. CONST. amend. XIV.

${ }^{168}$ See U.S. CONST. amend. XIII.

${ }^{169}$ See Steamship, 73 U.S. (6 Wall.) at 34-35.

${ }^{170}$ See Brentwood Acad. v. Tenn. Secondary Sch. Athletic Ass'n, 531 U.S. 288, 298 (2001).

${ }^{171}$ See supra note 22 and accompanying text.

${ }^{172}$ Kelo v. City of New London, 545 U.S. 469, 478 (2005).

${ }^{173}$ Here, the regulatory takings doctrine backstops the constitutional requirement that just compensation be provided for the taking of private property. 
standard $^{174}$ to Penn Central Transportation Co. v. City of New York's ${ }^{175}$ considerations of "economic impact," "investment-backed expectations," and "character of the governmental action." "176

This is true even with Justice Scalia's attempt in Lucas v. South Carolina Coastal Council ${ }^{177}$ to create a categorical rule that a taking occurs any time "regulation denies all economically beneficial or productive use of land." ${ }^{178}$ After announcing this rule-like test, Justice Scalia undercut its precision in two respects. First, he admitted that there remained some question as to what might constitute "deprivation of all economically feasible use." 179 Second, he provided an exception to the rule for "restrictions that background principles of the State's law of property and nuisance already place upon land ownership." 180

Finally, the myriad purpose and effects tests that pervade constitutional doctrine, though they may look rule-like at first blush, often operate as standards designed to prevent governmental actors from simply enacting facially neutral laws cleverly drawn to circumvent decision rules. There is a rule-like ring to pronouncements such as, "no speech prohibition based on content," "no discrimination based on race," "no discrimination against out-of-state commerce," and so on. In practice, however, these pronouncements work as standards because the Court rarely announces what sorts of evidence and how much will prove purpose or which effects and how many are required to demonstrate forbidden effects. It leaves those decisions to the discretion of subsequent courts for application ex post.

\section{$* * *$}

AEDs typically are decision rules fashioned as standards that, in turn, ensure that governmental officials cannot easily evade or undermine constitutional commands by formal compliance with rule-like decision rules implementing those constitutional commands. As we have demonstrated here, AEDs have been present from nearly the beginning of the Court and appear in all areas of constitutional law.

In Part III, we argue that there are substantial benefits to optimizing the enforcement of constitutional principles through the use of AEDs. Those benefits are accompanied by trade-offs, however, which we also identify and assess.

\section{BENEFITS AND TRADEOFFS OF ANTI-EVASION DOCTRINES}

Backstopping decision rules with standards that curb officials' ability to evade constitutional principles with superficial compliance has benefits as well as

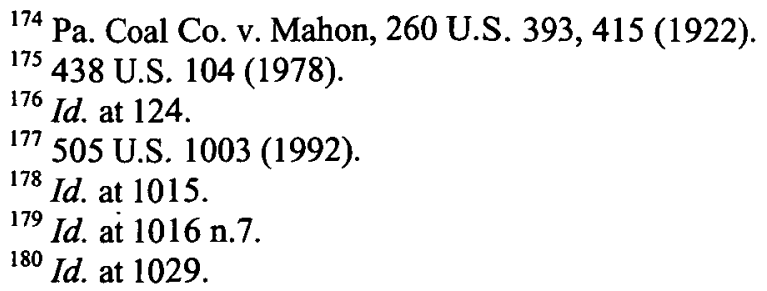


drawbacks for constitutional doctrine. On the plus side, anti-evasion doctrines help optimize enforcement of constitutional principles by making them more difficult to evade and address the "problems with rules" that can plague decision rules expressed as simple rules. But the use of AEDs is not cost-free, as we make clear in Part III.B. First, their use tends to make constitutional doctrine more complex, which in turn raises decision costs for judges employing that doctrine. Multiplying decision rules, thus increasing doctrinal complexity, also raises the danger of the slippage between decision rules and the principles they were intended to implement-what Professor Roosevelt has termed "calcification."181 Finally, because AEDs tend to take the form of standards, they are freighted with all of the disadvantages of ex post lawmaking. In other words, as surely as AEDs address some of the problems with rules, they introduce into doctrine the problems with standards.

\section{A. Benefits}

\section{AEDs Optimize Enforcement of Constitutional Principles}

One obvious benefit of AEDs' frequent appearance in constitutional law is that their deployment enables courts to refine and, in theory, optimize their enforcement of constitutional principles. Were government actors able to act in ways that formally comply with legal rules, but nevertheless achieve the same substantive result the rule was intended to prevent, not only would constitutional principles go unvindicated, but it is likely that those principles would degrade over time, perhaps even disappearing or lapsing through desuetude. ${ }^{182}$ The simple fact that AEDs have long been put to work in a wide variety of doctrinal settings suggests that the Court is not willing to tolerate underenforcement of some constitutional principles. The primary way in which AEDs do this, in our view, is by taking the form of standards bolstering those rules, concomitantly remedying what Professor Sunstein once termed "problems with rules."

${ }^{181}$ Roosevelt, supra note 6.

${ }^{182}$ In the early twentieth century, obviously before the passage of the 1965 Voting Rights Act, the Fifteenth Amendment was so frequently and blatantly violated around the country-especially in the South-that calls went out for its repeal. See, e.g., Goldwin Smith, Is the Constitution Outworn?, 166 N. AM. REV. 257, 257-67 (1898); see also Arthur W. Machen, Jr., Is the Fifteenth Amendment Void?, 23 HARV. L. REV. 169, 179-91 (1910) (arguing that because the Fifteenth Amendment cannot be enforced in all the states, it should be void).

${ }^{183}$ Sunstein, supra note 29. 


\section{AEDs Address "Problems with Rules"}

\section{(a) Rules, Standards, and Constitutional Doctrine}

A version of the rules-versus-standards debate plays out in American constitutional law. ${ }^{184}$ Professor Sullivan, for example, famously sorted members of the Rehnquist Court according to their preferences for rules or standards. ${ }^{185}$ The questions raised are identical to those posed in other areas of the law. When the Court implements constitutional meaning, should it employ rules (e.g., "no content-based regulation of speech") or standards (e.g., "evenhanded laws burdening interstate commerce are valid unless the burden on interstate commerce clearly exceeds local benefits")?

Commentators, including the Justices themselves, ${ }^{186}$ often argue that rules are better for reasons including economy, predictability, stability, and equality. In a famous article, Justice Scalia, a long-time champion of clear rules, argued that it is preferable in law "to have a clear, previously enunciated rule that one can point to in the explanation" of judicial decisions, "even at the expense of the mild substantive distortion that any generalization introduces." ${ }^{\text {187 }}$ Rules are said to offer the following benefits: (1) by treating like cases alike, they promote fairness; ${ }^{188}$ (2) they constrain official discretion; ${ }^{189}$ (3) they increase predictability; ${ }^{190}$ (4) they increase efficiency by enabling officials to make quick decisions at relatively low cost $;^{191}$ and (5) they are transparent relative to decisionmaking via standards.

${ }^{184}$ See, e.g., Scott Dodson, The Complexity of Jurisdictional Clarity, 97 VA. L. REV. 1, 23-59 (2011) (discussing the difficulties and trade-offs inherent in designing "clear" rules for complex situations; using examples from civil procedure).

${ }_{185}$ See Sullivan, supra note 15 (sorting the Justices' preferences in the 1991 term).

${ }^{186}$ See, e.g., Scalia, supra note 160 , at $1179,1182$.

${ }^{187} \mathrm{Id}$. at 1178 .

${ }^{188}$ Sullivan, supra note 15 , at 62.

${ }^{189}$ SCHAUER, supra note 160, at 192 ("[T] continuum can be understood as a device for constraining or withdrawing discretion."); Scalia, supra note 160, at 1180 ("Only by announcing rules do we hedge ourselves in."); see also FARNSWORTH, supra note 160, at 165 ("Rules usually are better than standards for controlling subordinates or other partners who aren't perfectly trusted . . .."); Sullivan, supra note 15, at 77 (noting that rules in constitutional adjudication "eliminate[] judicial discretion to filter the Constitution through contestable contemporary political or moral theories").

${ }^{190}$ SCHAUER, supra note 160 , at 193 ("[A] per se rule is likely to give far more information about likely consequences of action than a less determinate standard."); Scalia, supra note 160 , at 1179.

191 FARNSWORTH, supra note 160 , at 167 (noting that while rules are expensive to generate, they are usually less costly to apply); SCHAUER, supra note 160, at 193; Sunstein, supra note 29, at 972-74 (arguing that rules minimize the informational and political costs of making decisions). 
(b) "Problems with Rules"

\section{i. Over- and Underinclusiveness}

But as Professor Sunstein has pointed out, rules have downsides. ${ }^{192}$ Rules, he noted, are often under- and overinclusive. ${ }^{193} \mathrm{~A}$ rule, for example, mandating that pilots retire at sixty, aimed at ensuring optimal physical fitness and mental acuity, is underinclusive, because it will fail to weed out pilots under sixty who have prematurely deteriorated mentally or physically. It is also overinclusive because it forces out those over sixty who are in prime condition, losing in the bargain their experience and judgment.

A striking feature of AEDs is how their appearance as standards seems tailor made to meet many of the shortcomings of rules. As one example, AEDs fill gaps in previously established decision rules, helping to address the underinclusive nature of rule-like devices. Consider the dormant Commerce Clause doctrine (DCCD). An important decision rule enforcing the DCCD is that states may not discriminate against interstate commerce. ${ }^{194}$ Notice it is framed as a rule. But discrimination could simply be cleverly concealed - a state could, for example, simply ban the import of a competing product ${ }^{195}$ or tax it in a way that advantages its in-state competitors. ${ }^{196}$ Thus, the no-facial-discrimination rule, standing alone, is underinclusive. Problems of underinclusiveness are diminished, however, when AEDs prohibiting discrimination in purpose or effect bolster this antidiscrimination rule. Similarly, the Smith Court ruled that generally applicable laws with incidental effects on religious observance do not violate the Free Exercise Clause, ${ }^{197}$ but the Court later held that ostensibly generally applicable laws whose purposes or effects targeted a particular religion were prohibited. ${ }^{198}$ Consider also the jurisprudence surrounding the Tonnage Clause, in which the Court has held that even levies based on something other than a ship's literal tonnage are subject to invalidation if the levies accomplish the same ends. ${ }^{199}$

\footnotetext{
192 Sunstein, supra note 29 , at 978.

${ }^{193} \mathrm{Id}$. at 992 .
}

194 As one of us has argued at length elsewhere, this decision rule slightly overenforces the constitutional principle that states ought not be able to regulate interstate commerce in ways that increase the risk of interstate friction, harming national unity. During the Confederation era, targeting the goods coming from other states was a paradigm example of such activity. Denning, supra note 6, at 484-87.

195 See, e.g., Hunt v. Wash. State Apple Advertisers Comm'n, 432 U.S. 333, 333 (1977).

\footnotetext{
${ }^{196}$ See, e.g., Bacchus \& Imps., Ltd. v. Dias, 468 U.S. 263, 263 (1984).

${ }^{197}$ Emp't Div. v. Smith, 494 U.S. 872, 892 (1990).

${ }^{198}$ Church of the Lukumi Babalu Aye, Inc. v. Hialeah, 508 U.S. 520, 533 (1993).

${ }^{199}$ See supra notes 75-82 and accompanying text.
} 


\section{ii. Changed Circumstances}

An additional problem with rules occurs as a result of changed circumstances. Because rules are formulated ex ante, there is a possibility that if the factual predicates that informed the rule change, it will be difficult to update the rule thereafter. ${ }^{200}$ To take our pilot retirement example again, the mandatory retirement may have made sense when formulated. With advances in medical care and changes in lifestyle, however, the average sixty-year-old may be in better shape than someone who was forty-five or fifty when the mandatory retirement age was set. And yet decisionmakers applying the rule would have few legitimate ways to incorporate those changed circumstances into their judgments.

Again, AEDs help to mitigate the problem. Formulating AEDs as standards provides judges with a hedge against a rule that has become outdated owing to changed circumstances. Designers of rules lack omniscience and are unable to foresee all possible circumstances that a rule needs to anticipate. Bolstering rules with AEDs expressed as standards, however, allows rules to be supported in the face of factual settings that were not anticipated at the time the rule was derived. It may have been difficult, for example, to anticipate how committed Texas was to keeping African-Americans from voting in its primaries. Though the Fifteenth Amendment prohibited states from withholding voting rights on the basis of race, Texas tried "privatizing" the primaries and the parties. ${ }^{201}$ The Court responded with an AED that prevented such gambits. ${ }^{202}$

\section{iii. Conceals Discretion}

Another difficulty with rules is that while they purport to constrain those applying them, discretion is frontloaded. The line-drawing choices made in rule formation, moreover, can be arbitrary and mask bias. ${ }^{203}$ Returning to our example, those making our hypothetical rule may have chosen sixty because it was a nice round number or because they were biased against older pilots. Or it could have been a reasoned judgment made in light of the available evidence. Or sixty-two might have been a better age. The point is that the concrete end-product of rulemaking conceals the choices made in rule formation; those choices, moreover, may reflect bias, laziness, or informational shortcomings of the designers.

But there is another sense in which the use of rules conceals the exercise of discretion, this time at the point of application instead of at the point of rule formation. As Professor Schauer has observed, courts and regulators can engage in rule-avoidance techniques that enable them to sidestep the consequences of a

200 Sunstein, supra note 29, at 993; see also Dodson, supra note 184 , at 52-53 (arguing that standards' concomitant uncertainty and discretion can "improve accuracy" by "provid[ing] opportunities for courts to better implement and accommodate the underlying policies in given circumstances").

${ }^{201}$ Terry v. Adams, 345 U.S. 461, 469-70 (1953) (plurality opinion).

${ }^{202}$ Id. at 469-70.

${ }^{203}$ Sunstein, supra note 29, at 994. 
particular rule. ${ }^{204} \mathrm{~A}$ common rule-avoidance technique in constitutional law is to define particular categories of activity as lying outside the scope of the rule itself. For example, the First Amendment subjects content-based regulations of speech to strict scrutiny-except that there are certain categories of speech (obscenity, "fighting words," true threats, incitement to illegal activity) deemed to lie outside the protection of the First Amendment-categories defined by the content of the speech. ${ }^{205}$ In another example, the Court has exempted discrimination against interstate commerce in favor of public entities from the usual rule that discrimination against interstate commerce is subject to heightened scrutiny. ${ }^{206}$ Deciding what is and is not covered by a given rule involves an exercise of discretion, but is not as transparent an exercise as, say, deciding whether an individual's interest in expression was outweighed by some competing governmental or societal interest - a classic exercise of discretionary balancing. ${ }^{207}$

Whether concern is focused at the rule-formation or rule-application stage, AEDs help to foster more transparency in constitutional adjudication. Because AEDs typically supplement rule-like decision rules with standard-like decision rules, they temper any previous concealment of judicial discretion occasioned by the formulation of the earlier rules. By taking the form of standards, which operate ex post to increase the discretion of the decisionmaker, AEDs overtly bring the exercise of judicial discretion back into the analysis, making it more difficult to conceal.

\section{iv. Fosters "Doctrinal Arbitrage"}

Paradoxically, the clarity and relative precision of rules also enable governmental actors to disregard them. As Professor Sunstein notes, "Because rules have clear edgès, they allow people to 'evade' them by engaging in conduct that is technically exempted but that creates the same or analogous harms." ${ }^{208}$ Put differently, rules create formal enforcement gaps that can encourage a form of regulatory arbitrage - call it doctrinal arbitrage.

${ }^{204}$ Schauer, supra note 31 , at 312-15.

${ }^{205}$ In United States v. Stevens, 130 S. Ct. 1577 (2010), however, the Court turned aside the government's attempts to expand the categories of speech that lack First Amendment protection. Id. at 1585-86.

${ }^{206}$ See United Haulers, Inc. v. Oneida-Herkimer Solid Waste Mgmt. Auth., 550 U.S. 330, 342-46 (2007); see also Dep't of Revenue v. Davis, 553 U.S. 328, 341-43 (2008) (applying the public-entities exception to discriminatory tax exemption for income derived from state-issued bonds). For criticism of this exception, see Norman R. Williams \& Brannon P. Denning, The "New Protectionism" and the American Common Market, 85 Notre DAME L. ReV. 247, 255-61 (2009).

${ }^{207}$ For a good example of the latter, see New York v. Ferber, 458 U.S. 747, 756-64 (1982) (frankly balancing the harms associated with child pornography against the "de minimis" First Amendment interests of permitting the material to circulate).

${ }^{208}$ Sunstein, supra note 29, at 995. 
The term "regulatory arbitrage" is borrowed from finance and describes the situation occurring when a target of regulation "uses differences between economic substance and regulatory position to evade unwelcome regulation." ${ }^{209}$ In essence, the target uses form to evade the substance of a rule, where a gap in the law permits such evasion. As we use it here, "doctrinal arbitrage" refers to the opportunities for governmental actors to elevate form over substance by achieving ends prohibited by rule-like decision rules indirectly.

One of the prime benefits of AEDs is that they function to fill the gaps left by rule-like decision rules, thus reducing opportunities for doctrinal arbitrage. AEDs blur the sharp edges of rules with the uncertainty and unpredictability of standards, thus raising costs to governmental actors that would use a rule's clarity and precision to undermine the constitutional principle the rule was intended to enforce. ${ }^{210}$ In fact, the possibility of some form of doctrinal arbitrage has led some scholars to argue against rule-like clarity in deciding constitutional cases, suggesting that the more actors know about where lines are drawn by the Court, the more they can focus on either regulating right up to the line (which might produce more regulation than when the line between the permitted and the prohibited was blurred) or on evading the rule altogether. Criticizing the Pentagon Papers case, ${ }^{211}$ for example, Professor Bickel wrote that the "conditions in which government will not be allowed to restrain publication are now clearer and perhaps more stringent than they have been." ${ }^{212}$ But, he cautioned,

We are, or at least we feel, freer when we feel no need to extend our freedom. The conflict and contention by which we extend freedom seem to mark, or at least to threaten, a contraction; and in truth they do, for they endanger an assumed freedom which appeared limitless because its limits were untried. ... We extend the legal reality of freedom at some cost in its limitless appearance. And the cost is real. ${ }^{213}$

209 Regulatory Arbitrage, BUSINESSDICTIONARY.COM, http://www.business dictionary.com/definition/regulatory-arbitrage.html (last visited Oct. 27, 2012). See generally Victor Fleischer, Regulatory Arbitrage, 89 TEX. L. REV. 227, 229 (2010) ("Regulatory arbitrage exploits the gap between the economic substance of a transaction and its legal or regulatory treatment, taking advantage of the legal system's intrinsically limited ability to attach formal labels that track the economics of transactions with sufficient precision." (citation omitted)).

${ }^{210}$ Cf. Stephenson, supra note 6, at 11,50-52 (arguing that courts can and should craft constitutional decision rules to raise costs to legislatures enacting constitutionally dubious laws).

${ }^{211}$ N.Y. Times Co. v. United States, 403 U.S. 713 (1971).

${ }^{212}$ AleXANDER M. BiCKel, The Morality of CONSENT 61 (1975).

${ }^{213}$ Id. Professor Dodson notes that uncertainty "can encourage healthy competition between legal actors" and can encourage debate over underlying principles. Dodson, supra note 184 , at 54 . "The idea here is that different systems work best when they are engaged with each other over their proper jurisdictional boundaries, as opposed to staying pacifically on their own side of the fence." Id. He adds, "clearly defined rules may stifle thoughtful discussion, competition may stimulate it." Id. 
Clearly defined limits invite regulation up to the very edge of those limits. The predictability with which rules are applied may reduce the costs of legislating to that line. In many areas, however, AEDs provide some assurance that efforts to establish some clarity and predictability cannot. be turned against the principles they were intended to implement through easy evasion or form-over-substance gamesmanship.

\section{v. Substitute Procedural for Substantive Fairness}

As a "rule of law" value, procedural fairness requires impartial and evenhanded application of the law according to criteria that are easily discovered. But Professor Sunstein describes another form of "due process," one which "urges that people should be allowed not merely to test the application of law to fact, but also to urge that their case is different from those that have gone before . ..,214 In other words, concepts of substantive fairness inform individuals' overall assessment of whether a given procedure is fair or not. Rules by and large privilege formal, procedural equality. In individual circumstances, however, this can work hardship and seem terribly unfair.

Consider a set of parents with two teenage children, Anna and Britta. The parents have announced to their children that curfew is 11:00 p.m. and that the sanction for violating curfew is confinement to the home (school excepted) for ten days. Friday evening, Anna arrives home at 11:30 p.m. because she had a flat tire and had to call a wrecker to replace the tire before she could get home. Britta arrives home at 1:30 a.m. because she was at a party she was not supposed to attend. Applying the rule, the parents ground both children for ten days. One can easily see how Anna might take cold comfort from the fact that the rule was evenhandedly applied. Her grounding seems unfair relative to her sister's. It is more just to treat Anna and Britta's violations of curfew differently, given the facts, than it is to treat only one fact-that both were late-as dispositive. At the very least, Anna should be given an opportunity to explain why her situation warrants different treatment. Indeed, responding to just such concerns, the authorities of medieval England saw fit to create courts of equity to temper the hard edges of the common law.

Here, too, AEDs help provide a solution. AEDs can promote a kind of substantive fairness, as opposed to offering simple procedural fairness - but not in the usual way described in the rules-versus-standards debate. Instead of enabling those subject to a rule to explain how their situation differs and why they should not be subject to the rule, AEDs extend the reach of the rule to activities not quite covered by it in a formal sense. Despite this difference, we still believe that the impulse to prevent governmental actors from elevating official form over constitutional substance-to engage in doctrinal arbitrage-proceeds from the same sense of fairness and justice that would be offended from similar treatment

${ }^{214}$ Sunstein, supra note 29 , at $995-96$. 
for Anna and Britta, above. Judges, too, share the sense that the Constitution prohibits underhanded as well as ham-handed attempts to violate its provisions and that it would be unfair and unjust to allow constitutional principles to be undermined by subterfuge and artifice. This sense, we argue, is what motivates judges to formulate AEDs in the first place.

\section{B. Tradeoffs}

It would be Panglossian of us, however, to present AEDs as an unqualified good in constitutional doctrine. Their creation and maintenance come at a cost, and we examine the tradeoffs in this section. For all their utility, AEDs undoubtedly contribute to doctrinal complexity. This, in turn, increases decision and error costs for the judiciary, and it may result in a diminished perception of the Court's legitimacy. Moreover, the proliferation of decision rules raises the specter that, as these rules are continuously refined, areas of doctrine can fall prey to what Professor Roosevelt termed "calcification"215 - that is, the conflation of the decision rule with the underlying principle it was designed to implement. Perhaps most importantly, the standard-like nature of AEDs, while addressing problems with rules, introduces the problems with standards.

\section{AEDs Contribute to Doctrinal Complexity}

As you might recall when you made an outline for constitutional law, the doctrines that implement that document can be maddeningly complex. Balancing formulas, three-part tests, and oft-forgotten exceptions abound. Doctrine-AEDs included-can be complicated, bewildering stuff, as demonstrated by Professor Berman's "first and partial stab" at "a comprehensive statement of judicial doctrine effectuating"216 the First Amendment's command that "Congress shall make no law ... abridging the freedom of speech"217.

A law constitutes an impermissible abridgment of the freedom of speech if: it regulates expression on the basis of its content or viewpoint and is not narrowly tailored to achieve a compelling governmental interest, except that content-based regulation of non-misleading speech that proposes a lawful economic transaction is permitted if the regulation directly advances a substantial government interest that could not be advanced equally well by a less speech-restrictive regulation, and except too that content-based regulation of speech is freely permitted if, inter alia, the regulated speech proposes an unlawful economic transaction or

${ }^{215}$ Roosevelt, supra note 6.

${ }^{216}$ Mitchell N. Berman, Constitutional Constructions and Constitutional Decision Rules: Thoughts on the Carving of Implementation Space, 27 CONST. COMMENT. 39, 39 (2010).

${ }^{217}$ U.S. CONST. amend. I. 
a lawful transaction in a misleading way, or if it is sexually explicit and as a whole appeals to the prurient interest, and depicts or describes sexual conduct in a patently offensive way, and lacks serious artistic, political, or scientific value, or if it includes the sexually explicit depiction of children, or if the speech, by its very utterance inflicts injury or tends to incite an immediate breach of the peace; all subject to the caveat that even when speech may permissibly be regulated, if that regulation takes the form of a prior restraint on its issuance, then the regulation is ordinarily presumptively impermissible; and furthermore, a content-neutral regulation of speech is impermissible unless it is narrowly tailored to achieve a significant government interest and leaves open ample alternative channels of communication. ${ }^{218}$

Even this statement, Professor Berman acknowledged, was incomplete, ${ }^{219}$ but if we tried to replicate his efforts for equally brief clauses found elsewhere in the Constitution, we suspect that our sentences would resemble Professor Berman's.

Nearly twenty years before Professor Berman clearly distinguished the act of interpreting constitutional provisions to fix meaning and designing decision rules to implement that meaning, Professor Nagel sensed that was what the Court was doing and condemned what he termed "the formulaic constitution" in no uncertain terms. ${ }^{220}$ The Court, he noted, had adopted "a new style of opinion writing" that "emphasizes formalized doctrine expressed in elaborately layered 'tests' or 'prongs' or 'requirements' or 'standards' or 'hurdles.",221 'Professor Nagel contrasted this complexity of the Court's opinions about the Constitution with the simplicity and generality of the constitutional text itself. ${ }^{222}$ Although the text speaks "both authoritatively and modestly," 223 the Court's decisions speak in the language of the bureaucrat and the academic-complicated, multifaceted, vague, and using words in a "puzzlingly artificial way."224

What emerge, he complained, are complex doctrinal pronouncements that attempt to synthesize formalism and realism, ${ }^{225}$ with largely negative results. First, the authority of the constitutional text is displaced. ${ }^{226}$ Second, multiple and inconsistent demands are propagated. ${ }^{227}$ Finally, judicial efforts are improperly

${ }^{218}$ Berman, supra note 216 , at 39-40.

${ }^{219}$ Id. at 40 ("I have not yet said anything about those portions of the doctrine that govern defamation, intentional infliction of emotional distress, or invasion of privacy, or limited public fora, or campaign finance expenditures, or the speech of public employees, and so on.").

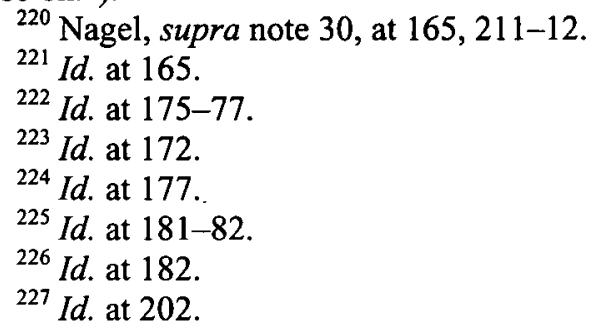


devoted to formulating doctrine itself rather than to deciding specific, factbased controversies. ${ }^{228}$

To Professor Nagel, this was all nonsense. Using doctrine, courts, judges, and scholars had interposed themselves between the Constitution and its "primary constitutional meaning,"229 sometimes to the point where the doctrine they created seemed to contradict the understanding of the text itself. Moreover, this doctrinal subversion of the Constitution did not even have clarity or precision as virtues. Further, Professor Nagel doubted that the formulae judges employed constrained anyone at all. ${ }^{230}$

Whatever the cause of Professor Nagel's formulaic Constitution, ${ }^{231}$ AEDs definitely contribute to the proliferation of the rules and standards that make up the warp and woof of constitutional decision rules. While complexity might benefit the lawyers who litigate these cases and advise others of their meaning, complexity can frustrate and bewilder the public, confuse lower courts charged with deciphering and applying the Court's work product, and make it difficult for lawmakers to predict what the Court will do. All of these drawbacks, in turn, can make the Court's decisions seem more arbitrary, thus damaging the Court's reputation as a legitimate institution. AEDs contribute to this complexity even as they serve the purpose of making the Court's decisions more refined and optimizing the constitutional principles they are intended to implement. But the cost in complexity is there and must be acknowledged.

\section{AEDs Increase Decision Costs}

In addition, AEDs and their attendant complexity raise decision costs for judges and justices applying them. A relatively clear, precise rule--"No State shall, without the Consent of Congress, lay any Duty of Tonnage," for examplerequires comparatively little from those applying it. First, one has to determine what is a tonnage duty. Once established that a tonnage duty is a levy imposed on a

${ }^{228}$ Id. at $203-05$.

229 Id. at 182. Professor Nagel wrote that the formulaic style "foreclose[d] independent judgment by the wider publics that are affected by the decisions but that have no special claims to understanding or authority." Id. at 195. Anyone who has ever stopped a conversation with a layperson about the Constitution by saying, "Well, the Court doesn't read [insert constitutional provision here] that way," is familiar with this phenomenon, often to the dismay of the interlocutor who is left wondering how the Court can elevate itself above the document that created it.

${ }^{230} \mathrm{Id}$. at 202 ("Despite their superficial precision, neither the content nor the shape of modern formulae communicates clarity and constraint.").

${ }^{231}$ As we make clear here, we do not agree that courts create AEDs out of either a desire for complexity for its own sake or out of desire to confuse laypersons to ensure the need for both lawyers and courts in dispute resolution. But see BENJAMIN H. BARTON, THE LAWYER-JUDGE BIAS IN THE AMERICAN LEGAL SYSTEM (2011) (arguing in part that complexity is a design feature of American law motivated in part by the desire to benefit lawyers and judges). 
vessel calculated on its carrying capacity, ${ }^{232}$ it is fairly easy to decide whether a given tax or duty fits the definition. It either does or it does not. So far, so good.

But when you graft on an AED, which says a tonnage duty is a tax levied on a vessel's carrying capacity and "all charges, whatever their form, that impose ' $a$ charge for the privilege of entering, trading in, or lying in a port, ${ }^{, " 233}$ a host of other questions arise. In addition to ascertaining whether or not the levy is a tonnage duty, the judge also has to decide whether the challenged levy is close enough to a pure tonnage duty to warrant invalidation. To do that, the judge will have to assess what is really being taxed, where the incidence of the tax falls, what the motives of the legislature were, and so on. For each of these questions, evidence may be inconclusive or simply unavailable.

Consider, too, the various purpose and effects tests the Court applies in areas as varied as free speech, free exercise, and the dormant Commerce Clause doctrine. It's all well and good to say that facially neutral laws having discriminatory effects or that target religious observance are subject to heightened scrutiny, but judges must then articulate which effects count as discriminatory and how those effects might be proved. The same goes for purpose tests: How does one prove a discriminatory purpose by an official body? How prevalent need the purpose have been? What evidence suffices? Legislative reports? Floor statements? Diary entries?

Examples could be multiplied, ${ }^{234}$ but the point remains that attempts to prevent nonobvious constitutional violations increases the costs to judges of rendering decisions. This, in turn, means that false positives (permissible laws invalidated) or false negatives (impermissible laws upheld) may increase. Given the difficulty of revising the Supreme Court's constitutional decisions (and of gaining Supreme Court review of erroneous constitutional decisions by lower courts), whatever aid is rendered by using AEDs to vindicate constitutional principles might be offset by an overall increase in errors in the system. It might simply exceed the capacity of the average judge to make and apply AEDs-at least when they are constructed as standards that require careful attention to facts. ${ }^{235}$

${ }^{232}$ BITTKER, supra note 76 , at $12-38$ to -39 .

${ }^{233}$ Polar Tankers, Inc. v. City of Valdez, 557 U.S. 1, 9 (2009) (emphasis added).

234 To offer one more recent example, Justice Ginsburg complained about the uncertainty Chief Justice Roberts's coercion test would likely sow among lower courts. Nat'l Fed'n of Indep. Bus. v. Sebelius; 132 S. Ct. 2566, 2640 (2012) (Ginsburg, J., concurring in part and dissenting in part) ("When future Spending Clause challenges arrive, as they likely will in the wake of today's decision, how will litigants and judges assess whether 'a State has a legitimate choice whether to accept the federal conditions in exchange for federal funds?"').

${ }^{235}$ See generally ADRIAN VERMEULE, JUdGING UNDER UNCERTAINTY (2006) (proposing that judges' insulation from politics prevents the awareness of changing social conditions necessary to design interpretive decision procedures). 


\section{AEDs Create the Possibility of "Calcification"}

Building on Professor Berman's distinction between constitutional operative propositions and their implementing decision rules, ${ }^{236}$ Professor Roosevelt identified certain pathologies of judicial decisonmaking that occur when the Court conflates the two. ${ }^{237}$ This conflation could produce minor and major effects, the latter of which he termed "calcification." ${ }^{238}$ As decision rules that assist other decision rules in the implementation of operative propositions, AEDs perform a backstopping or gap-filling function when initial decision rules inadvertently underenforce an operative proposition, to the ultimate detriment of that principle. Therefore, AEDs might be susceptible to either the minor or major mischief that Professor Roosevelt identifies.

The minor problems that can crop up are (1) loss of fit, and (2) subterfuge. Loss of fit occurs when decision rules designed under one set of facts are confronted with changes in facts that render those earlier decision rules untenable ${ }^{239}$ For example, the women's movement that hit its stride in the 1970 s created problems for the Court, which previously had applied rational basis review to sex-based classifications. One response to the loss of fit between the growing sense that most such classifications were the product of bias and the Court's deferential review would have been to replace rational basis review with strict scrutiny to reflect societal suspicion of sex-based classifications' legitimacy. Instead the Court maintained rational basis review, but applied it in a more aggressive, less deferential manner. ${ }^{240}$ In so doing, the Court engaged in what Professor Roosevelt terms subterfuge, ${ }^{241}$ in which the Court applies the decision rules in ways that produce the opposite outcome from the one expected by the usual operation of the decision rules employed in the cases. ${ }^{242}$ Lawrence $v$. Texas $^{243}$ and Grutter v. Bollinger ${ }^{244}$ are two recent examples of this practice.

On the minor issues of loss of fit and subterfuge, AEDs score quite well. They are, after all, a response to loss of fit between decision rules and the operative propositions caused by a failure to close off avenues of evasion, creativity by would-be violators, and the like. By performing this function, AEDs could potentially extend the useful life of decision rules-shoring them up as experience

${ }^{236}$ Berman, supra note 216 , at 41.

${ }^{237}$ Roosevelt, supra note 6, at $1658-67$.

${ }^{238} \mathrm{Id}$. at $1692-93$.

${ }^{239} \mathrm{Id}$. at $1686-87$.

${ }^{240}$ See, e.g., Reed v. Reed, 404 U.S. 71 (1971); see also Gerald Gunther, The Supreme Court, 1971 Term-Foreword: In Search of Evolving Doctrine on a Changing Court: A Model for a Newer Equal Protection, 86 HARV. L. Rev. 1, 32-34 (1972) (discussing Reed and its use of a more rigorous form of rational basis review).

${ }^{241}$ Roosevelt, supra note 6, at 1689.

${ }^{242}$ Calvin Massey, The New Formalism: Requiem for Tiered Scrutiny?, 6 U. PA. J. CONST. L. 945 (2004).

${ }^{243} 539$ U.S. 558 (2003).

244539 U.S. $306(2003)$. 
reveals gaps. By keeping judges focused on the underlying principles and encouraging optimal enforcement of them, AEDs potentially enable "judges to engage the underlying policies, explore them, try them in different circumstances, discard them when they no longer make sense, and generally enhance the systemic and dynamic understanding" of constitutional doctrine. ${ }^{245}$

AEDs would not seem to serve as a convenient vehicle for subterfuge either. The purpose of AEDs, after all, is to optimize existing decision rules, not to furnish a means of avoiding their application. In any event, subterfuge is not caused by decision rules per se; it is the result, rather, of the justices themselves declining to apply those rules honestly. No set of rules or standards discharges its function if it is unfaithfully, dishonestly, or haphazardly applied.

Professor Roosevelt is critical of subterfuge ${ }^{246}$ but calcification was his main worry about a Court that conflates decision rules with constitutional operative propositions. The source of the danger is easy enough to pinpoint:

In its early encounters with a particular constitutional provision, the Court tends to stay quite close to the constitutional operative proposition. As time passes, doctrine becomes more complex. Judicial experience with the sort of problems presented by adjudication under a particular provision leads to the development of decision rules that depart from the operative proposition. When initially articulating such decision rules, the Court frequently explains what it is doing, and why-that, for instance, it is deferring to congressional determinations about effects on commerce because of legislative competence, or that it is ratcheting up the level of scrutiny for gender-based discrimination because of pervasive prejudice and stereotyping. ${ }^{247}$

But, he cautions, "when a stable jurisprudential regime has persisted for a period of time, decision rules can start to be mistaken for constitutional operative propositions. When this happens, a number of undesirable consequences follow," such as "ill-advised doctrinal reform, attempts to bind nonjudicial actors to decision rules rather than operative propositions, and an undoing of the benefits of decision rules." 248

${ }^{245}$ Dodson, supra note 184 , at 54.

${ }^{246}$ However useful subterfuge is in reducing cognitive dissonance among the justices, it has a number of negative effects, according to Professor Roosevelt. The technique "is confusing to lower court judges, who must puzzle out how to follow a Court whose words diverge from its practice." Roosevelt, supra note 6, at 1691. (And, he might have added, to lawmakers and other officials who might be crafting legislation in light of the Court's ruling.) It also makes the Court "appear arrogant, unprincipled, or both. It suggests a lack of faith in either the lower courts or the unannounced rule, or perhaps a belief that society will not accept it." Id.

${ }^{247}$ Id. at 1692 .

${ }^{248}$ Id. at 1693. 
Doctrine can be warped when a "court . . . discard[s] decision rules not because they have lost fit but because they do not make sense as operative propositions. Alternatively, it may accept them as operative propositions and make other doctrinal changes, in the same or related fields, in order to maintain consistency."249

Conflating decision rules and operative propositions also has the effect of judicializing the Constitution-creating what Professor Tushnet called "judicial overhang" that might unduly influence nonjudicial debates about the Constitution. ${ }^{250}$ "When the Court treats its decision rules as operative propositions, it announces as constitutional truths rules that should neither be followed by nonjudicial actors nor internalized by the general public. ${ }^{, 251}$

AEDs might present calcification problems unless designers remember that it is the constitutional principle they are ultimately trying to implement, not other decision rules. AEDs will no doubt build on existing decision rules, but they should not focus exclusively on the latter's effective implementation.

An example from the dormant Commerce Clause doctrine can illustrate the point. As noted earlier, the Court enforces the core of the DCCD with an antidiscrimination rule. Facially discriminatory laws and regulations are presumptively unconstitutional. This rule is supplemented by three AEDs: a purpose test, an effects test, and Pike balancing. Under the latter, even nondiscriminatory regulations for which there is no evidence of discriminatory purpose or effect may nevertheless be invalidated if the burdens on interstate commerce exceed the claimed local benefits. ${ }^{252}$ Pike balancing may represent the sort of calcification that Professor Roosevelt warned against. ${ }^{253}$ The test is the lineal descendant of earlier tests that measured the permissibility of state and local regulation by whether the subject of the legislation was national or local, or whether the regulation directly or indirectly regulated interstate commerce. ${ }^{254}$ These decision rules, in turn, were a rough attempt to operationalize the intuition that the Constitution imposed limits on the states' ability to regulate commerce among the states. ${ }^{255}$

But if one accepts the argument that the constitutional operative proposition at work in the DCCD is that states may not regulate interstate commerce in ways that threaten to undermine political union-as opposed to, say, the principle that

${ }^{249}$ Id

${ }^{250}$ Mark V. Tushnet, TAKing The Constitution Away from the Courts 5465 (1999).

${ }^{251}$ Roosevelt, supra note 6, at 1713 ; see also id. at 1717 ("When the Court . . comes to believe that the meaning of the Constitution is exhaustively specified by a list of what judges will uphold or strike down-it denies nonjudicial actors their appropriate role in implementing the Constitution."); cf. Nagel, supra note 30, at 182-83 (complaining about the formulaic Constitution).

${ }^{252}$ See supra note 214 and accompanying text.

${ }^{253}$ Denning, supra note 6 , at $453-56$.

${ }^{254}$ Id. at $435-40$ (describing this doctrinal evolution).

${ }^{255}$ Id . at $428-31$. 
congressional control over interstate commerce is quasi-exclusive-then Pike balancing is a poor decision rule for implementing that meaning. At most, one might argue that Pike aids in eliminating covert discrimination, but then the Court's energies might be better spent more clearly articulating what factors figure into a decision that a facially neutral statute has discriminatory purposes or effects. ${ }^{256}$

The DCCD, of course, does not exhaust the universe of potentially calcified constitutional doctrines that employ AEDs. To take an example from the past, when the Court was interpreting Congress's Article I, section 8 powers against a background assumption that certain powers were reserved to the states exclusively, its decision rules tended toward calcification. Seeking to prevent pretextual regulations that invaded these reserved powers, the Court created decision rules that required Congress to regulate only those things having a "direct effect" on interstate commerce, meaning that "the activity or condition invoked ... shall operate proximately - not mediately, remotely, or collaterally - to produce the effect, ${ }^{, 257}$ which excluded from regulation things like mining, agriculture, and manufacture. The Hammer Court seems to have similarly distorted decision rules in the service of these background assumptions by concluding that Congress had the power to prohibit interstate shipment of "inherently harmful" goods. ${ }^{258}$ As critics noted both at the time and later, these decision rules seemed to collapse meaning and doctrine unduly, narrowing the scope of congressional power in the name of another, dubious constitutional principle protecting nontextual aspects of state sovereignty. ${ }^{259}$

Fear of calcification might be what causes the Court to refrain from expanding or fully developing nascent AEDs. ${ }^{260}$ While the Court has suggested that, at some point, conditions on receipt of federal funds by states could become "coercive" and thus exceed congressional power, ${ }^{261}$ it has not suggested where that line resides, and it took twenty-five years for the Court finally to conclude that a spending condition crossed it. ${ }^{262}$ One can envision future courts bogging down in a

${ }^{256} \mathrm{Id}$. at $493-94$.

${ }^{257}$ Carter v. Carter Coal Co., 298 U.S. 238, 307 (1936).

${ }^{258}$ Hammer v. Dagenhart, 247 U.S. 251, 271 (1918); see supra text accompanying notes $46-53$.

259 See, e.g., 9 Alexander M. BiCkel \& Benno C. Schmidt, JR., The Oliver Wendell Holmes DeVise, History of the SuPREME COURT OF THE UNITED STATES: THE JUDICIARY AND RESPONSIBLE GOVERNMENT 1910-21, at 451-52 (1984); DAVID P. CURRIE, The Constitution IN the Supreme Court: The SeCond Century, 1888-1986, at 9798 (1990).

260 See Brannon P. Denning \& Michael B. Kent, Jr., Anti-anti-evasion in Constitutional Law (Sept. 2012) (unpublished manuscript), available at http://papers.ssm.com/sol3/papers.cfm?abstract_id=2126733/ (discussing the significance of the Court's failure to create and implement anti-evasion doctrines).

${ }^{261}$ South Dakota v. Dole, 483 U.S. 203, 211 (1987).

${ }^{262}$ Nat'l Fed'n of Indep. Bus. v. Sebelius, 132 S. Ct. 2566, 2603-07 (2012) (plurality opinion); id. at 2658-67 (joint dissent). 
morass of decisions attempting to articulate the line between coercive and permissible conditions ${ }^{263}$-much as the Court did when it attempted to ascertain what were and were not "traditional governmental functions" during the period after National League of Cities v. Usery, ${ }^{264}$ before the Garcia case brought that experiment to an end. ${ }^{265}$

If the chances of calcification increase as decision rules multiply, and if those decision rules have as their object not some constitutional principle but the implementation of prior decision rules, then the presence of AEDs in a given doctrine could contribute to calcification. But nothing suggests that AEDs would be more susceptible to calcification or would accelerate the conflation of operative propositions and decision rules. In fact, in Professor Roosevelt's article, he singles out the Court's implementation of the Equal Protection Clause's antidiscrimination principle as a prime example of calcification. ${ }^{266}$ By requiring proof of discriminatory intent, however, and prohibiting claims for disparate impact (a form of effects test), ${ }^{267}$ the Equal Protection Clause is one area in which the Court seems to have decided not to adopt a full range of AEDs. In fact, as we argue below, by attempting to optimize enforcement of constitutional principles themselves, AEDs may even help inoculate doctrine against calcification. ${ }^{268}$

\section{AEDs Replace the "Problems with Rules" with the "Problems with Standards"}

Rules' strengths are commonly held to include predictability, consistency, transparency, and the ability to constrain judicial discretion. ${ }^{269}$ For rule proponents, standards' weaknesses are mirror images of those strengths. Standards are alleged to be unpredictable, to result in inconsistent application, to foster opaqueness, and

${ }^{263}$ See id. at 2640-41 (Ginsburg, J., concurring in part and dissenting in part) (predicting future difficulty in applying coercion test).

${ }^{264} 426$ U.S. 833 (1976).

${ }^{265}$ Garcia v. San Antonio Metro. Transit Auth., 469 U.S. 528 (1985).

${ }^{266}$ Roosevelt, supra note 6, at 1700-07.

${ }^{267}$ Washington v. Davis, 426 U.S. 229, 242 (1976). The Court did concede in the next term that sometimes intent could be inferred from context. See Vill. of Arlington Heights v. Metro. Hous. Dev. Corp., 429 U.S. 252, 266-68 (1977). Scholars have criticized the Court for making it difficult to prove discriminatory intent when a law or policy is facially neutral, suggesting that the limited purpose AED furnished by Arlington Heights is of limited use. See generally Daniel Ortiz, The Myth of Intent in Equal Protection, 41 STAN. L. REV. 1105, 1105-06, (1989) (criticizing the Court's limited focus on the process of decisionmaking and not on the substantive fairness of the outcomes). See Charles R. Lawrence III, The Id, the Ego, and Equal Protection: Reckoning with Unconscious Racism, 39 STAN. L. REV. 317, 320-21, (1987) (discussing the doctrine of discriminatory purpose and suggesting a different way to think about racial discrimination that is more focused on the origins and effects of racial discrimination); David A. Strauss, Discriminatory Intent and the Taming of Brown, 56 U. CHI. L. REV. 935, 937 (1989) (arguing that the discriminatory intent standard is inadequate).

${ }^{268}$ See infra text accompanying notes 340-344.

${ }^{269}$ See supra notes $184-214$ and accompanying text. 
to promote discretion. Critics of standards argue that they invite rather than constrain judicial discretion. This discretion, in turn, makes standards unpredictable in their application, thus reducing certainty for policymakers and legislators-as well as for lower court judges. Discretion also raises the specter of arbitrary or uneven application in particular cases. Critics also argue that standards sometimes require judges to make complicated empirical judgments and that standards conceal contested value judgments from scrutiny. ${ }^{270}$ To the extent that AEDs regularly take the form of standards, they too are vulnerable to those critiques. As we argue in the next section, however, AEDs furnish judges with a powerful tool to adjust doctrine to optimize enforcement of constitutional principles. In exchange for that, we are willing to accept the problems with standards. ${ }^{271}$

\section{Assessing Anti-Evasion Doctrines}

Despite these tradeoffs, we believe that AEDs are, on balance, valuable in constitutional law. In this section, we explain why by analogizing AEDs-and doctrinal design generally-to a form of "risk analysis." AEDs embody what Professor Hirschman termed "the mature position."

When we think about risk regulation, the usual actors that come to mind are administrative agencies, which issue evidence-based regulations to implement broad goals identified by legislatures and embodied in legislation. There is voluminous literature concerning the optimal level of risk regulation. When it comes to regulating health and safety, some advocate a so-called precautionary principle-the principle that "new technologies and policies should be rejected unless and until they can be shown to be safe."273 Other risk regulators prefer costbenefit analysis-admittedly "a protean term"-which "encompass[es] everything from informal consequentialism ... to a formal, fully monetized analysis of compensating variations based on willingness to pay and to accept."274

${ }^{270}$ For critiques of standards, as opposed to rules, see, for example, Dale A. Nance, Rules, Standards, and the Internal Point of View, 75 FORDHAM L. REV. 1287, 1288-90 (2006); and Scalia, supra note 160; and compare Samuel L. Bray, Announcing Remedies, 97 CORNELL L. REV. 753 (2012), for an argument that announcing remedies ex ante can be preferable to specifically tailoring remedies to particular wrongs for reasons similar to those given for preferring rules to standards.

${ }^{271}$ In addition, as we note later, AEDs offer a powerful example of the convergence of rules and standards, which may mean that the choice between the two is not as stark as the debate currently suggests. See infra notes 345-353 and accompanying text (discussing Professor Schauer's "convergence thesis").

${ }^{272}$ Our thoughts here were inspired by Adrian Vermeule, Precautionary Principles in Constitutional Law (Harvard Pub. Law, Working Paper No. 11-20, 2011) (last revised Mar. 16, 2012), available at http://ssrn.com/abstract $=1930427 /$.

\footnotetext{
${ }^{273}$ Id. at 1.

${ }^{274}$ Id. at 27.
} 
But other governmental actors and institutions, besides administrative agencies, engage in risk regulation. In a recent paper, for example, Professor Vermeule canvassed precautionary principles in provisions of the U.S. Constitution, in constitutional doctrine, and in modalities of constitutional interpretation and argumentation. ${ }^{275}$ Picking up on Professor Vermeule's comparison, we would argue that retail-level doctrinal design is a form of risk regulation undertaken by judges attempting to implement, and optimize enforcement of, broad constitutional principles. Just as regulators must translate their mandate into regulations that address risks, judges must craft decision rules that, among other things, over- or underenforce constitutional commands drawing on a variety of factors that inform how weak or strong the decision rules will be, whether they will take the form of rules or standards, and the like. ${ }^{276}$

As we have suggested throughout this Article, however, decision rule formation is a continuous process, not a one-time event. ${ }^{277}$ Thus, courts will constantly revisit situations that call for the application of the decision rules created to cover particular situation types. AEDs offer judges the ability to respond to unanticipated risks to constitutional principles that emerge over time. This means that judges need not embrace calls for maximal protections for constitutional principles-that is, for a doctrinal equivalent of the precautionary principle. With new technologies or policies, employing maximal protections comes at the cost of stifling innovation and depriving the public of useful-even life-saving-policies or technologies in the face of uncertain, perhaps even illusory, risks. Similarly, in constitutional law, maximal judicial protections for constitutional principles might entail a similar stifling of innovation that can make government run more efficiently, increase public safety, enhance national security, or provide sought-after public goods. Maximal protections may also involve undesirable or intolerable second-guessing of electorally accountable officials.

In the clamor for constitutional protection against risk, moreover, those seeking to apply some version of the precautionary principle often ignore considerations such as the fact that "the status quo itself carries risks [or] that the costs of . . principles may outweigh the benefits." ${ }^{278}$ After all, anticipated risks might not materialize; if they do, AEDs can be crafted ex post to meet the risk. And if we are correct that AEDs generally take the form of standards as opposed to rules, the blurring of the lines between constitutional and unconstitutional official action can serve to deter future violations.

Because the creation and application of AEDs endeavor to achieve "optimal precautions rather than maximal precautions,"279 we would argue they are

${ }^{275} \mathrm{Id}$.

${ }^{276}$ For good discussions of these factors and their role in decision rule formation, see Berman, supra note 6, at 93-95; and Roosevelt, supra note 6, at 1658-67. For a summary, see Denning, supra note 6, at 489-91. See also Stephenson, supra note 6 (discussing how doctrinal rules can raise costs for legislatures seeking to implement policies).

277 See Baker \& Kim, supra note 160 (offering a dynamic model of doctrinal formation).

${ }^{278}$ Vermeule, supra note 272 , at 1.

${ }^{279}$ Id. at 27. 
analogous to the "mature position" suggested by Professors Hirschman and Vermeule. ${ }^{280}$ According to the latter, "The mature position implies that . . . the institutional system for interpreting and enforcing the $[\mathrm{C}]$ onstitution ... should take into account all relevant risks, on all sides of relevant questions." ${ }^{281}$ The process of crafting and implementing initial decision rules and then backstopping them with AEDs, to our minds, closely resembles such a system. Through this process, the Court sets initial rules based on the relevant information available to it and then revises and supplements those rules based on risk considerations that subsequently arise. In this way, over time, the Court qua risk regulator achieves a more balanced risk assessment, enabling it to craft exceptions and standards that soften its prior decision rules in ways that reach more desirable outcomes. ${ }^{282}$

These outcomes, of course, take substantive form in the actual doctrine formulated as a result of the Court's process. But we think that the process itself achieves desirable effects apart from the rules and standards that flow from it. One of the significant functions of the "mature position" Professor Vermeule identifies is that "it places tradeoffs on the 'viewscreen' and thereby excludes unconstrained demands for 'maximal safety' or 'security' against perceived risks." ${ }^{283}$ We see similar benefits in the Court's fashioning of AEDs. Despite the problems that AEDs raise, on balance, they help to create transparency and intentionality in the adjudicatory process. Like the "mature position," AEDs "help to serve as a valuable intellectual corrective, by placing all relevant risks before constitutional designers, constitutional interpreters, and the public who ultimately judges both."284 The development of AEDs focuses judicial, legislative, and public attention on the many factors that need to be considered in achieving optimal enforcement of constitutional principles, and indeed brings to light the question of what level and type of enforcement is optimal in the first instance. Focus on these considerations promises to make the process of formulating constitutional doctrine more deliberative and less impassioned, which in turn promises to improve the substantive doctrine resulting from that process.

\section{IMPLICATIONS FOR CONSTITUTIONAL DOCTRINE}

Apart from their relevance in the rules-versus-standards debate, AEDs have implications for constitutional doctrine more generally. As an initial matter, the pervasiveness and historical pedigree of AEDs help explain, to some degree, why constitutional doctrine is so complex. As demonstrated above, AEDs are part of the Court's struggle to enforce constitutional principles at an optimal level. Their primary function is to fill gaps left by oversimplified decision rules, gaps that

\footnotetext{
${ }^{280} I d$. at $26-27$.

$281 \mathrm{Id}$. at 30.
}

${ }^{282}$ Dodson, supra note 184 , at 54 ; see also id. at 57 (describing a mix of certain and uncertain doctrinal rules as a "hybrid doctrine that uses a clear rule to address the easiest cases and an uncertain rule to address the harder cases").

${ }^{283}$ Vermeule, supra note 272, at 31 (citation omitted).

${ }^{284} \mathrm{Id}$ 
enable governmental actors to maintain formal compliance with the rules while simultaneously skirting the propositions those rules were designed to implement. In short, they serve as attempts to ensure that form will not trump constitutional substance. This interstitial function and the struggle of which it is a part almost inevitably will result in doctrine that seems "messy" or "muddled." Moreover, the ubiquity of AEDs indicates that such complexity is an inherent feature of constitutional adjudication. The "formulaic Constitution" famously criticized by Professor Nage ${ }^{285}$ may indeed be necessary for the system to work as it should. The existence and function of AEDs suggest that calls for simple, predictable, and easily applied decision rules should be met with a certain amount of skepticism.

Additionally, the presence of AEDs seems to substantiate Professor Schauer's "convergence hypothesis," which concerns the adaptive behavior of actors who are asked to conform to rules or standards. ${ }^{286}$ According to Professor Schauer's thesis, actors subject to rules tend to avoid some of the strictures of those rules and provide more discretion than the rules intend. ${ }^{287}$ Similarly, actors subject to standards tend to impose rule-like devices on themselves, thereby limiting the discretion that the standards were designed to foster ${ }^{288}$ The result of this convergence is that the two categories tend to meld together such that "the distinction between rules and standards collapses in practice."289 AEDs provide evidence for the convergence thesis in two respects. First, the efforts of government actors to evade constitutional principles while formally adhering to established decision rules, as well as the Court's struggle to curb such evasion through backfilling standards, lends credence to Professor Schauer's notions about adaptive behavior. Second, the very need to employ a mixture of both rules and standards to achieve optimal enforcement of a constitutional principle confirms the idea that, when doctrinal areas are viewed holistically, the distinction between rules and standards will be much less significant than might first appear.

Finally, noticing and understanding the AED phenomenon suggests that the formation and implementation of constitutional doctrine, as well as doctrine itself, should be taken seriously. As one of us has noted previously, the recent focus in constitutional scholarship on "macro-level doctrinal formation" has yielded several benefits. ${ }^{290}$ Our focus here on AEDs strengthens the claim that the background principles of doctrinal formation are a matter of high importance and worthy of continued scholarly attention.

${ }^{285}$ See generally Nagel, supra note 30, at 169 (arguing that the Court's adopted formulaic style is "obtrusively elaborate rather than economical or elegant").

${ }^{286}$ Schauer, supra note 31 , at 312.

${ }^{287}$ Id. at $312-13$.

${ }^{288} \mathrm{Id}$.

${ }^{289} I d$. at 311.

${ }^{290}$ Denning, supra note 10 , at 790 . 


\section{A. The Inevitability of the Formulaic Constitution}

Although we share some of Professor Nagel's criticisms, discussed above, about the style of modern judicial opinions, we find his core implication-that simpler and more predictable pronouncements would alleviate the complexity of constitutional doctrine-to be unconvincing. Rather, we conclude that a certain amount of complexity and technicality is inevitable, and AEDs serve as evidence for this conclusion. Moreover, we also think that the use of AEDs goes a long way toward answering his complaints about displacement of the constitutional text, inconsistency, and misdirection of judicial focus.

First, notwithstanding any simplicity of the original document, implementing the Constitution in an optimal way-one of the core functions of AEDs-is inherently difficult and is bound to require more than reiterations of the text itself. As Professor Dodson has argued in a similar context, attempts at clarity often come at considerable cost to underlying values, and he urges that we not "overvalue the mantra of clarity and simplicity."291 Second, recognizing that anti-evasion is an overarching theme in constitutional adjudication helps to explain some of the perceived inconsistencies in constitutional doctrine. Finally, AEDs, despite being doctrinal pronouncements themselves, nonetheless serve as attempts to avoid an overemphasis on doctrine by responding to specific factual contexts that have eluded earlier doctrinal formulations.

\section{Constitutional Application, Formulaic Language, and Anti-Evasion}

One can hardly disagree that the text of the Constitution is simpler, loftier, and generally more accessible than the multifaceted, "highly abstract legal jargon"292 that the Court's opinions often include. Thus, there is some validity to Professor Nagel's criticism that the Court's pronouncements about the Constitution are a poor substitute for the document itself. ${ }^{293}$ Were the Constitution written in the language of a judicial opinion, it indeed would appear "complicated," "hesitant," "confusing," and even "contrived."2294

To say these things, however, is not to say that the Court's constitutional pronouncements-even with their complicated, multipart tests-are illegitimate. The Constitution and the Court serve different purposes. The Constitution addresses fundamentals, sets basic parameters, and lays out objectives. ${ }^{295}$ It edifies, motivates, stirs, and inspires. ${ }^{296}$ It establishes a common narrative for the American

${ }^{291}$ Dodson, supra note 184 , at 55 . He adds, "When clarity is attained . . . it so deviates from its underlying purposes as to be of questionable justification." Id.

${ }^{292}$ Akhil Reed Amar, The Supreme Court, 1999 Term-Foreword: The Document and the Doctrine, 114 HARV. L. REV. 26, 46 (2000).

${ }^{293}$ See Nagel, supra note 30, at 175-76 (comparing text of First Amendment and Commerce Clause to Court's pronouncements about these provisions).

${ }^{294} \mathrm{Id}$.

${ }^{295}$ McCulloch v. Maryland, 17 U.S. (4 Wheat.) 316, 407 (1819).

${ }^{296}$ Amar, supra note 292, at 27; Nagel, supra note 30, at 172-73. 
people despite their different backgrounds and beliefs. ${ }^{297}$ It is a grand and majestic document. But the Constitution is not everything, and it cannot accomplish everything. The Constitution is not a comprehensive legal code, ${ }^{298}$ nor (as Professor Nagel seemingly admitted) is it easily applied in every situation. ${ }^{299}$ It must be interpreted; its meaning must be identified in the context of disputed cases. That is part of the Court's function.

Importantly, however, constitutional interpretation is only one of the Court's functions. In addition to identifying the meaning of the text, the Court must also determine the method of successfully implementing that meaning. ${ }^{300}$ To perform that task, "the Court often must craft doctrine that is driven by the Constitution, but does not reflect the Constitution's meaning precisely."301 As discussed earlier, there is a difference between fixing constitutional meaning and fashioning decision rules that put that meaning into action. ${ }^{302}$ These two judicial functions are related, but they are not identical.

Thus, any evaluation of constitutional jurisprudence should be conducted through the lens of both of these judicial outputs-the operative proposition of any given textual provision and the decision rules that give that proposition effect in individual cases. ${ }^{303}$ In his critique, however, Professor Nagel seemed to conflate the two outputs. For example, Professor Nagel praised Justice Roberts's statement in United States v. Butler ${ }^{304}$ that the Court can do no more than "announce its considered judgment upon [a constitutional] question.",305 For him, this approachsimpler and more modest--better preserves the authority of the original text than does a resort to formulae:

If in the end a court can do more than announce its judgment about the meaning of the constitutional text ..., that text remains separate from the court's opinion about it. When a court claims something more ambitious--when it seeks to demonstrate rather than to announce- there is correspondingly less reason to distinguish the external authority from the court's opinion. . . . [T]he judicial construction comes to be

${ }^{297}$ Amar, supra note 292 , at 47.

${ }^{298}$ Cf. Mc Culloch, 17 U.S. (4 Wheat.) at 407.

299 See Nagel, supra note 30, at 176 (noting "absolutism of the language" of First Amendment and Commerce Clause but conceding that "neither provision is absolute, because each is so general and cryptic").

${ }^{300}$ Richard H. Fallon, Jr., The Supreme Court, 1996 Term-Foreword: Implementing the Constitution, 111 HARV. L. REV. 54, 57 (1997).

${ }^{301}$ Id.

${ }^{302}$ Berman, supra note 6, at 36 (noting "conceptual distinction between two sorts of judicial work product," i.e., "constitutional meanings" and "constitutional rules").

${ }^{303}$ Id. at 57-58; see also Berman, supra note 8, at 220-21 (proposing that Constitutional judicial decisions fall into two categories: "constitutional operative propositions" or "constitutional decision rules").

${ }^{304} 297$ U.S. 1 (1936).

${ }^{305}$ Nagel, supra note 30, at 184 (quoting Butler, 297 U.S. at 62-63). 
interchangeable with the original text. Interpretation can then stand in the place of the original text. ${ }^{306}$

Clearly, there is a danger that the Court (and others) will come to treat its doctrinal pronouncements as a substitute for the text itself. But this issue most likely occurs as a result of "constitutional calcification"-that is, confusing the Court's decision rules with the constitutional principles they are designed to implement. ${ }^{307}$ Indeed, Professor Nagel appears to have made this same mistake. His focus in the above-quoted passage was on constitutional interpretation (i.e., determining the operative proposition of the text), yet much of the "formulaic" language that troubled him seems to come from the Court's attempts at implementation (i.e., creating decision rules that practically apply the operative proposition) ${ }^{308}$ Whatever its merits with regard to determining the operative proposition of a constitutional text, a simple announcement generally works less well when it comes time to enforce that proposition in actual controversies. ${ }^{309}$

This is true for a variety of reasons. To start, "general propositions do not decide concrete cases." 310 Structure must be provided to present and future litigants, and a resolution to the controversy must be found. In addition, several other considerations might influence the crafting of decision rules: (1) institutional competence, (2) error costs, (3) fiscal concerns, (4) interbranch relations, (5) optimizing implementation, (6) historic or democratic reasons for underenforcement or overenforcement, (7) ideas about constitutional justice, and (8) the level of acceptability of the rule despite reasonable disagreement about constitutional norms. ${ }^{311}$

Although these considerations may in some contexts suggest a decision rule that closely tracks the operative proposition of a constitutional text, in many circumstances, such an approach will prove insufficient. Consider again the Takings Clause. The text of the Fifth Amendment provides that "private property [shall not] be taken for public use, without just compensation." ${ }^{, 12}$ If the Court interprets the word "taken" to be nothing more than the appropriation of property by the government via eminent domain, then a decision rule implementing the operative proposition may be relatively simple and closely aligned to the text

${ }^{306}$ Id.

${ }^{307}$ Roosevelt, supra note 6, at 1693.

${ }^{308}$ Cf. David L. Faigman, Constitutional Adventures in Wonderland: Exploring the Debate Between Rules and Standards Through the Looking Glass of the First Amendment, 44 HASTINGS L.J. 829, 833 (1993) ("Most of the time, if not always, constitutional rules take shape at the application stage.").

${ }^{309}$ Indeed, Professor Nagel seems to admit as much: "[T]he form appropriate for the original document is not necessarily appropriate for its application." Nagel, supra note 30, at 177 .

${ }^{310}$ Roosevelt, supra note 6 , at 1658 .

311 These considerations are collected and discussed in Denning, supra note 6, at 489$91 \&$ n.423.

${ }^{312}$ U.S. CONST. amend V. 
itself - that is, the government must have a public purpose and pay compensation when it uses its eminent domain power. But if the word "taken" means more, if other types of government action can "take" private property even where eminent domain is not used, then such a rule leaves the operative proposition underenforced. There may be valid reasons for that underenforcement, and there may not be. Perhaps more accurately, there may be valid reasons to underenforce the operative proposition in some cases, but not in others. In such a scenario, finding the proper balance to achieve optimal enforcement is difficult. It requires more than simply referring to the text or its meaning; rather, it necessitates the crafting (and sometimes recrafting) of rules to guide judicial determinations in specific cases. Given the number of potentially relevant considerations, a certain amount of doctrinal intricacy is not only to be expected, but may also be necessary.

The anti-evasion pattern we identify in this Article is central to this optimization. As such, AEDs help to reinforce the notion that crafting simple decision rules is not easy. Returning to the Takings Clause, if the word "taken" in the Fifth Amendment is interpreted to cover more than appropriation by eminent domain, but the decision rule enforcing the Takings Clause only applies when eminent domain is affirmatively used, then the government can easily avoid the constitutional principle while simultaneously adhering to the decision rule. Rather than condemn property under its eminent domain power, the government could simply regulate private property in a manner that accomplishes the same objectives. To counter such attempts at evasion, the Court would need to develop different decision rules that apply the protections of the Takings Clause to scenarios other than the affirmative use of eminent domain.

But what scenarios should be covered? Should all regulation of private property obligate the government to pay compensation? If not, which sorts of regulatory action will trigger the takings protections and which will not? Answering these questions-questions that are directly related to optimal enforcement of the constitutional provision - is a complicated process that must take into account the institutional competence of the judiciary, the democratic nature of legislative decisions, the purposes for which private property might be regulated, the potential for error resulting from any rule that might be established, the acceptability and predictability of the rule for future cases, and, of course, the need to curb future evasion. When the process of fashioning decision rules is evaluated in this light, it is little wonder that the Court's takings doctrine is "muddled." The task confronting the Court is not simple, and therefore, the resulting rules - as well as the language used to convey them-are not likely to be simple either.

In fact, Professor Nagel acknowledged the connection between anti-evasion and formulaic language. Criticizing the Court's doctrinal statements as too closely resembling the language of bureaucrats, Nagel nonetheless noted that bureaucratic language has its place. "Bureaucratic language," he wrote, "can be useful ... within official hierarchies. Within organizations, the complexity and completeness is aimed at preventing predictable efforts at evasion .... The use of bureaucratic 
style by the Supreme Court is an effort to achieve similar purposes." ${ }^{313}$ The presence of AEDs reveals that the Court is not (or at least is struggling against) simply forsaking the meaning of the constitutional text to promote its own doctrinal assertions. To the contrary, the very existence of AEDs provides evidence that the Court seeks to apply the constitutional commands despite the fact that its own prior decision rules might allow those commands to be thwarted. This effort requires a certain amount of finesse, nuance, and elaboration. Anti-evasion, and the struggle of which it is a part-the struggle to take the meaning of the Constitution and apply it to multiple factual scenarios in an optimal manner-thus helps to explain the complexity of constitutional doctrine and hints that such complexity may be unavoidable if the system is to work as it should.

\section{Anti-Evasion as Counter to Perceived Inconsistencies}

Similarly, the existence of AEDs helps to explain why much constitutional doctrine seems to take the form of "multiple, repetitive, shifting, and sometimes inconsistent demands." ${ }^{314}$ In fact, many of the perceived inconsistencies in constitutional doctrine may themselves be the result of AEDs. As the Court labors to curb evasion of constitutional meaning despite adherence to its prior decision rules, new rules must be put in place. ${ }^{315}$ At first blush; these new rules will naturally seem different, perhaps even incompatible, with the rules established previously. This is not surprising given that their very existence results from the failure of the prior rules optimally to implement the Constitution in the first place. But by viewing the various rules together, with anti-evasion as a unifying theme, they begin to take on a more coherent shape.

The two examples with which we began this Article-the dormant Commerce Clause doctrine (DCCD) and regulatory takings-prove illustrative. Both of these areas are famously difficult and have often been described as incoherent. ${ }^{316}$ Of course, these descriptions are in many respects accurate, and we do not attempt to reconcile all of the potential inconsistencies here. Nor do we claim that all of the inconsistencies are, in fact, reconcilable. Nonetheless, we argue that the antievasion principle provides a rational starting point for explaining the inconsistencies and difficulties that define the Court's jurisprudence in these areas.

${ }^{313}$ Nagel, supra note 30 , at 178 (emphasis added).

${ }^{314} I d$. at 202.

${ }^{315}$ Again, although we see the typical pattern as the Court's creation of a rule-like decision rule, followed by a subsequent standard-like AED that supplements the earlier rule, nothing in our analysis particularly rests on whether these devices are created separately or simultaneously.

316 See, e.g., Denning, supra note 6, at 422 (describing DCCD as "notoriously difficult, resulting in cases with similar facts being decided differently, and the different outcomes justified on the basis of tendentious distinctions"); Michael B. Kent, Jr., Construing the Canon: An Exegesis of Regulatory Takings Jurisprudence After Lingle v. Chevron, 16 N.Y.U. ENVTL. L.J. 63, 63 (2008) (noting descriptions of regulatory takings doctrine as "muddled," "confused," and a "constitutional quagmire"). 
The determination that a law is or is not discriminatory very nearly determines the law's constitutionality under the DCCD, given the strict scrutiny applied to discriminatory laws as compared to the deference given to those that do not discriminate against out-of-state goods, services, or economic actors. And yet courts frequently complain that "there is no clear line separating the category of state regulation that is virtually per se invalid under the Commerce Clause, and the category subject to the Pike v. Bruce Church balancing approach., ${ }^{317}$ It is a short step from that observation to the conclusion that the DCCD "makes little sense, and has proved virtually unworkable in application." ${ }^{318}$ Even if one recharacterizes the antidiscrimination principle as a decision rule implementing (by perhaps overenforcing) a constitutional command that state regulation of interstate commerce should not imperil the political union the Constitution created, the rule that truly nondiscriminatory but burdensome regulations should nevertheless be invalidated is puzzling. ${ }^{319}$ But Pike balancing makes perfect sense as an AED - a way to ensure that cleverly concealed discrimination can be flushed out by a reviewing court. ${ }^{320}$

Another perennial puzzle is the notorious difficulty of ascertaining how, exactly, one should apply the DCCD's discriminatory effects and discriminatory purpose tests. In a previous article, one of us argued that the outcomes in Hunt v. Washington State Apple Advertisers Commission ${ }^{321}$ and Exxon Corp. v. Governor of Maryland, ${ }^{322}$ decided one year later, were simply irreconcilable and that "one or more unarticulated reasons for the holding dictated the outcome." ${ }^{323}$ But if you consider the discriminatory effects test in light of our theory of AEDs-that they are decision-rules-as-standards backstopping decision-rules-as-rules-then the difference in outcome becomes more tolerable. Standards by nature lack the precision and definition of rules. This is a feature, moreover, not a bug-although rules work well for the "easy cases," the overall idea is to keep officials uncertain as to the location of the boundary between permissible and impermissible regulation. AEDs thus allow both a backstop for principle-implementing rules and a means by which courts can make relatively fine-grained distinctions between superficially similar cases. Apparent inconsistencies at the margins are the price to be paid for optimal-as opposed to minimal or maximal-enforcement of

317 Brown-Forman Distillers Corp. v. N.Y. State Liquor Auth., 476 U.S. 573, 579 (1986).

${ }^{318}$ Camps Newfound/Owatonna, Inc. v. Town of Harrison, 520 U.S. 564, 610 (1997) (Thomas, J., dissenting).

319 Denning, supra note 6, at 493-94 (recommending that Pike balancing be abandoned in the DCCD).

${ }^{320}$ See, e.g., Kassel v. Consol. Freightways Corp., 450 U.S. 662, 671, 675-79 (1981) (plurality opinion) (concluding that state ban on double tractor-trailers found unconstitutional under Pike balancing, but suggesting that discriminatory purpose might have motivated passage).

\footnotetext{
321432 U.S. 333 (1977).

322437 U.S. 117 (1978).

${ }^{323}$ Denning, supra note 6, at 467.
} 
constitutional principles. And understanding that optimal enforcement, through the mechanism of AEDs, is part of the Court's goal in formulating doctrine helps to make that doctrine look less inconsistent than might appear at first blush.

In similar fashion, the doctrine of regulatory takings begins to take on a more coherent shape when viewed through the prism of anti-evasion. Indeed, antievasion principles seem to underlie the very notion that regulatory action might sometimes qualify as a taking in the first place. The need to prevent government from doing indirectly through regulation what it could not do directly through actual seizure (at least not without paying compensation) drives the Court's takings doctrine from start to finish.

Although the Court has struggled to articulate just when a taking will be deemed to have occurred, ${ }^{324}$ anti-evasion serves as the predominate thread that unites its tests in this area. Consider Justice Holmes's early formulation of the doctrine: "[W] hile property may be regulated to a certain extent, if regulation goes too far it will be recognized as a taking." ${ }^{325}$ To be sure, this standard provides little guidance for determining exactly when a regulation will qualify as a taking. Nonetheless, implicit in this language is the notion that the Court will not allow the government to do via regulation what it could not accomplish through outright appropriation. In fact, Justice Holmes went on to make this anti-evasion principle even more explicit, noting that "a strong public desire to improve the public condition is not enough to warrant achieving the desire by a shorter cut than the constitutional way of paying for the change., 326

Subsequent to Mahon, the Court has articulated a variety of different tests to aid in determining when a regulation "goes too far" and becomes a taking. In Penn Central, for example, the Court articulated the famous tripartite balancing test that considers the economic impact of the regulation, the investment-backed expectations of the property owner, and the character of the governmental action. ${ }^{327}$ Two years later, the Court announced the now-defunct standard that a regulation "effects a taking if [it] does not substantially advance legitimate state interests or denies an owner economically viable use of his land." ${ }^{328}$ Another two years after that, the Court held that any permanent, physical invasion of private property was a taking per se, regardless of any other considerations. ${ }^{329}$ The Court similarly has held that regulations resulting in the total economic deprivation of a parcel should comparably be accorded categorical treatment. ${ }^{330}$ These various tests

${ }^{324}$ This struggle partially results from the Court's failure to settle upon an operative proposition for the Takings Clause, despite offering several alternatives.

${ }^{325} \mathrm{~Pa}$. Coal Co. v. Mahon, 260 U.S. 393, 415 (1922).

${ }^{326} \mathrm{Id}$. at 416.

${ }^{327}$ Penn Cent. Transp. Co. v. City of New York, 438 U.S. 104, 124 (1978).

${ }^{328}$ Agins v. City of Tiburon, 447 U.S. 255, 260 (1980) (citations omitted), overruled by Lingle v. Chevron, U.S.A., Inc., 544 U.S. 528 (2005).

${ }^{329}$ Loretto v. Teleprompter Manhattan CATV Corp., 458 U.S. 419, 426 (1982).

${ }^{330}$ Lucas v. S.C. Coastal Council, 505 U.S. 1003, 1015 (1992). 
are not entirely cohesive, ${ }^{331}$ and they have (in the Court's own words) generated many "vexing subsidiary questions" about takings doctrine. ${ }^{332}$ Even so, they all relate to one central idea: checking governmental efforts to evade the constitutional requirement to pay just compensation for the taking of private property.

The Court's recent encounter with the question of judicial takings reinforces the anti-evasion bent of takings doctrine. In Stop the Beach Renourishment, Inc. v. Florida Department of Environmental Protection, ${ }^{333}$ a plurality of the Court opined that state judiciaries could "take" property by declaring "that what was once an established right of private property no longer exists." 334 The plurality did not address the precise relationship between its theory of judicial takings and its regulatory takings tests mentioned above, ${ }^{335}$ but the same anti-evasion characteristics are noticeable in both. Just as regulatory takings doctrine seeks to prevent the government from evading the just compensation principle by substituting regulation for condemnation, the plurality's theory of judicial takings is aimed at efforts to evade the just compensation principle by substituting judicial action for legislative action. ${ }^{336}$ Despite any problems or inconsistencies that may inhere in the Court's takings tests, this anti-evasion principle helps to join those tests together in a somewhat more intelligible way.

At the end of the day, AEDs provide a prism through which to evaluate the complexities and inconsistencies of the Court's doctrinal rules. Professor Nagel noted that much of the formulaic style seems designed to constrain judges from applying purely subjective and personal standards, although he doubted that this was actually accomplished. ${ }^{337}$ Doctrine, he argued, "must be sufficiently detailed and schematic to bind judges who otherwise might seem beyond the law." Whether judicial constraint is in fact a goal of doctrinal complexity-and if so, whether that goal has sufficiently been realized-are valid questions for which we do not provide answers. But we note that the existence of AEDs suggests that doctrinal complexity is at least related to another type of constraint-the need to constrain governmental actors from skirting their constitutional obligations, even when their actions comply with established decision rules. When the Court's many and varied doctrinal pronouncements are viewed from this vantage point, a more coherent pattern begins to emerge.

331 See, e.g., Lingle, 544 U.S. at 539 (admitting that "our regulatory takings jurisprudence cannot be characterized as unified").

${ }^{332} I d$.

333130 S. Ct. 2592 (2010).

${ }^{334} \mathrm{Id}$. at 2602.

335 See generally Michael B. Kent, Jr., More Questions Than Answers: Situating Judicial Takings Within Existing Regulatory Takings Doctrine, 29 VA. ENVTL. L.J. 143 (2011).

${ }^{336}$ See Stop the Beach Renourishment, 130 S. Ct. at 2601 ("It would be absurd to allow a State to do by judicial decree what the Takings Clause forbids it to do by legislative fiat.").

${ }^{337}$ Nagel, supra note 30 , at $197-98$.

${ }^{338}$ Id. at 197. 


\section{Anti-Evasion as an Attempt to Avoid Doctrinal Calcification}

Finally, while we previously identified AEDs as a possible source of calcification, it might be that they serve, conversely, to keep the Court's own decision rules from becoming ends in themselves. AEDs are efforts by the Court to ensure that the constitutional command does not get lost in the sea of decision rules, but rather is enforced despite the fact that those rules may receive formal compliance. In other words, AEDs are designed to "combine conceptualism with fact-responsiveness." ${ }^{339}$

Professor Nagel criticized the Court for spending an inordinate amount of energy on developing doctrine rather than on deciding cases. The Court's attention, he wrote, is "not directed at the actual resolution of cases at hand," but rather is devoted to "the preliminary issue of determining the proper test to be applied in a defined class of cases." ${ }^{\prime 40}$ Varying factual contexts are forced into the subsets defined by the Court's doctrine, and unexpected facts lead to the formulation of "a wholly different formula" or to the abandonment of the constitutional inquiry altogether. ${ }^{341}$ For Professor Nagel, this focus on doctrine rather than adjudication fundamentally altered the Court's role: "The modern Court's emphasis on doctrine selection expresses and consolidates a radical shift in role from adjudicator to regulator., 342

Any merit this criticism might have is mitigated by the pattern of AEDs highlighted in this Article. AEDs demonstrate that the Court is not overly devoted to doctrine for its own sake. When doctrine-in the form of established decision rules-does not lead to appropriate enforcement of constitutional norms, the Court will backstop that doctrine with other rules designed to ferret out and remedy evasive action. True, this process may generate the establishment of a "wholly different formula," in Professor Nagel's terminology, but this very act demonstrates a willingness to alter doctrine when doing so better implements the overriding constitutional principle. ${ }^{343}$ Similarly, the use of AEDs reflects fact responsiveness as the Court adjusts its decision rules to address evasive behavior. They are recognitions by the Court that, at the end of the day, it is an adjudicative body that must resolve real controversies by optimally implementing the Constitution. The decision rules it crafts are designed for that purpose and must be supplemented when they fail to achieve their intended objectives. And the very existence of AEDs suggests that the Court is generally committed to the proposition that substance trumps form-that is, that decision rules do not exist (and thus should not be glorified) for their own sake, but rather serve to advance

\footnotetext{
${ }^{339} \mathrm{Id}$. at 203.

${ }^{340} \mathrm{Id}$. at 203-04.

${ }^{341} I d$. at 190.

${ }^{342}$ Id . at $204-05$.

${ }^{343}$ Id. at 190.
} 
deeper purposes in the law. When nonjudicial actors threaten to circumvent those purposes, the Court will respond with new rules that fill the gaps.

\section{B. Anti-Evasion Doctrines and the Convergence Thesis}

This gap-filling process has implications for constitutional doctrine in another respect: It provides evidence for the argument that rules and standards tend to converge, an argument put forward most explicitly by Professor Schauer. ${ }^{344}$ While not discounting the genuine differences that exist between these two types of devices, Professor Schauer has contended that, as a practical matter, the choice between them may not matter as much as is often supposed. ${ }^{345}$ This is because regardless of whether a rule or standard is chosen to enforce a particular norm, those subject to the rule or standard - that is, those who must follow, interpret, and apply it-tend to adapt their behavior in ways that push each device toward the other. ${ }^{346}$

First, Professor Schauer noted that those subject to rules "will tend to convert rules into standards by employing a battery of rule-avoiding devices that serve to soften the hard-edges of rules." ${ }^{, 347}$ Such devices may take the form of exceptions, reasonableness qualifications, contextual overrides, or interpretative devices that rely more on the rule's purpose than on its precise phrasing. ${ }^{348}$ At the same time, these same actors, "when given few rules in the rules-standards sense, will make them themselves, and apply them to their own allegedly discretionary behaviour, thus limiting significantly the case-sensitive discretion that it was the intention of the rule-maker to grant. ${ }^{349}$ This is accomplished through such methods as the establishment of per se categories, incorporation of external rule-like devices into the standard, and giving the standard precedential effect in future cases. ${ }^{350}$ The simultaneous adaptation of both rules and standards, Professor Schauer posited, results in rule subjects approaching "the same point on the rules-standards continuum regardless of whether they were given rules or standards as their starting raw material." ${ }^{351}$ Consequently, "the choice between rules and standards makes far less difference than is generally believed to be the case." 352

344 See generally Schauer, supra note 31 (hypothesizing that adaptive institutional behavior minimizes the distinction between "rule" and "standard").

${ }^{345} \mathrm{Id}$. at 305 . For another take on adaptive behavior, see Dodson, supra note 184 , at 55 , which states, "Clear rules simply prove too much, and, despite good intentions of adhering to them, either rulemakers give up on designing them or courts erode them through exceptions and interpretations."

${ }_{346}$ See Schauer, supra note 31, at 305, 312.

${ }^{347}$ Id. at 312.

${ }^{348}$ Id. at $312-15$.

${ }^{349} \mathrm{Id}$. at 312.

${ }^{350} \mathrm{Id}$. at $316-19$.

${ }^{351} I d$. at 319.

${ }^{352} \mathrm{Id}$. (citation omitted). 
That constitutional doctrine exhibits signs of this convergence is apparent to a careful observer. As Professor Faigman noted almost two decades ago, "many constitutional results described as categorical [(i.e., rule-like)] are indistinguishable from a standards-based method." ${ }^{\text {353 }}$ It is our contention that the pattern of AEDs highlighted here helps explain the convergence effect in constitutional jurisprudence in at least two respects: (1) by providing evidence for Professor Schauer's theory of adaptive behavior, and (2) by demonstrating that such adaptive behavior results in a practical blurring of the differences between rules and standards.

\section{Anti-Evasion and Adaptive Behavior}

As an initial matter, the tendency of government actors to evade constitutional imperatives despite formal adherence to decision rules, as well as the Court's response to this evasion by crafting AEDs, demonstrates the validity of Professor Schauer's theory about adaptive behavior. When the Court establishes a given decision rule, those who must follow the rule devise methods that allow them to do so technically, while simultaneously thwarting the principle the rule was designed to safeguard. The result of this evasion is to give the rule follower more discretion in practice than the rule was designed to bestow in theory. The Court responds by employing another decision rule, usually framed in more standard-like language, to help curb these evasive efforts. In this regard, AEDs seem to fall within Professor Schauer's fourth example of rule-avoiding devices - that is, they tend to rely more on the purpose underlying the rule rather than the specifics of the rule itself. ${ }^{354}$ Pursuant to this pattern, both the actors that must follow the rule and the Court that interprets and applies it adapt their behavior in ways that render the rule more like a standard.

Examples of this adaptive behavior can be seen fairly clearly in the Court's jurisprudence surrounding the Fifteenth Amendment, which provides that "[ $t]$ he right of citizens of the United States to vote shall not be denied or abridged by the United States or by any State on account of race, color, or previous condition of servitude." ${ }^{.355}$ Early applications of the amendment straightforwardly observed that it rendered inoperative any laws that restricted the right of suffrage on the basis of race. ${ }^{356}$ In response, several states employed other voting requirements-such as literacy tests and certain registration schemes-that had the effect of limiting the voting rights of African-Americans. Because these requirements did not facially disturb the right of suffrage on account of race or any other prohibited characteristic, they technically complied with the previous rules enforcing the Fifteenth Amendment. Nonetheless, the Court invalidated them as violating the

\footnotetext{
${ }^{353}$ Faigman, supra note 308 , at 833.

${ }^{354}$ Schauer, supra note 31 , at 314-15.

${ }^{355}$ U.S. CONST. amend. XV, $\S 1$.

${ }^{356}$ See, e.g., Neal v. Delaware, 103 U.S. 370, 389 (1880).
} 
substance of that amendment. ${ }^{357}$ Hinting at the evasive nature of the requirements, the Court stated in one case, "The Amendment nullifies sophisticated as well as simple-minded modes of discrimination. 3358

\section{Anti-Evasion and the Distinction Between Rules and Standards}

In addition to confirming Professor Schauer's notions about adaptive behavior, AEDs also, and more significantly, demonstrate the tendency of constitutional rules and standards to converge. The adaptive behavior of those who must follow the Court's rules and the Court's adaptive behavior to backfill those rules with standards ultimately render the difference between the two devices less significant than is usually imagined.

AEDs, in other words, serve as agents of convergence. Through their creation and use, the decision rules governing a particular constitutional area ultimately employ both devices, such that the overall doctrine of that area really is a composite somewhere between a rule and a standard. As Professor Korobkin has observed:

Not all rules are pure rules; exceptions can render them standard-like in some circumstances. Similarly, not all standards are pure; reliance on precedent can make standards partially rule-like. At a certain point, rules can become so riddled with unpredictable exceptions that they are as much standard as rule, and standards can become so determinate that they are as much rule as standard; these composites reside in the "gray area" at the center of the spectrum. In more extreme cases, standards can become so determinate that they are transformed into rules, and rules so unpredictable that they are transformed into standards. ${ }^{359}$

It is our contention that AEDs operate to push constitutional doctrine, viewed holistically, into this "gray area," such that the distinction between rules and standards ends up having little practical difference.

Once again, Takings Clause jurisprudence is illustrative. The text of the Fifth Amendment and early decision rules implementing it can be viewed in rule-like terms: the government must provide compensation whenever it takes private property. ${ }^{360}$ If this restriction applies only to direct appropriation, then its rule-like characteristics are even more pronounced. Under such an application, direct appropriation requires the payment of compensation; injuries to property caused by

${ }^{357}$ See, e.g., Lane v. Wilson, 307 U.S. 268, 275-76 (1939) (registration scheme); Myers v. Anderson, 238 U.S. 368, 380 (1915) (registration scheme); Guinn v. United States, 238 U.S. 347, 364-65 (1915) (literacy test).

${ }^{358}$ Lane, 307 U.S. at 275.

${ }^{359}$ Russell B. Korobkin, Behavioral Analysis and Legal Form: Rules vs. Standards Revisited, 79 OR. L. REv. 23, 30 (2000).

${ }_{360}$ See, e.g., Monongahela Navigation Co. v. United States, 148 U.S. 312, 33637 (1893). 
other government action do not. ${ }^{361}$ Of course, as we have already seen, such a rule encourages evasive behavior by government officials, who can adapt their behavior to accomplish the same objectives as a direct appropriation through other, indirect means. In response to this evasion, the Court has held that regulatory action can "take" property under certain circumstances as well, thus requiring the same compensation as would a direct appropriation. ${ }^{362}$ Suddenly, the rule-like nature of the Takings Clause becomes more standard-like, with the Court deciding after the fact whether any particular government action has "taken" property. And, by and large, the Court has purposely eschewed any "set formula" for making that determination, relying instead on "essentially ad hoc, factual inquiries" driven by the circumstances of each case. ${ }^{363}$

In employing this standard-like decision rule, however, the Court has sought to limit discretion in certain contexts, treating certain types of regulation more categorically. Thus, the Court has declared that a regulation that requires an owner to suffer a permanent physical occupation of her property is a taking per se. ${ }^{364}$ So too has the Court declared categorical treatment appropriate for a regulation that deprives an owner of all economically productive use of her property. ${ }^{365}$ As a result, at least for these types of regulatory action, the standard-like framework governing takings cases once again becomes more rule-like in nature. Moreover, the precedential value of these holdings helps to reinforce their determinate nature.

But even these categorical rules are not pure rules. To keep them from limiting discretion too drastically, the Court has incorporated exceptions and nuances that allow more flexibility. For example, the Court has held that minor deductions from a monetary award to pay for government services used in obtaining that award are not occupations of property subject to the per se rule noted above. ${ }^{366}$ The Court explained:

It is artificial to view deductions of a percentage of a monetary award as physical appropriations of property. Unlike real or personal property, money is fungible. No special constitutional importance attaches to the fact that the Government deducted its charge directly from the award rather than requiring Sperry to pay it separately. If the deduction in this case were a physical occupation requiring just compensation, so would be any fee for services, including a filing fee that must be paid in advance. Such a rule would be an extravagant extension of Loretto. ${ }^{367}$

${ }^{361}$ See Legal Tender Cases, 79 U.S. (12 Wall.) 457, 551 (1871) (employing such a rule).

${ }^{362}$ See, e.g., Pa. Coal Co. v. Mahon, 260 U.S. 393, 415-16 (1922).

${ }^{363}$ Penn Cent. Transp. Co. v. New York City, 438 U.S. 104, 124 (1978).

${ }^{364}$ Loretto v. Teleprompter Manhattan CATV Corp., 458 U.S. 419, 426 (1982).

${ }^{365}$ Lucas v. S.C. Coastal Council, 505 U.S. 1003, 1015 (1992).

${ }^{366}$ United States v. Sperry Corp., 493 U.S. 52, 62 n.9 (1989).

${ }^{367}$ Id. 
But lest one think that this holding simply creates another rule-like distinction between real or personal property (which can be occupied) and money (which cannot), the Court applied the per se rule against physical occupations to monetary interests in a subsequent decision. ${ }^{368}$ This ability to apply the per se rule in some instances but not in others limits its "ruleness" and gives it a standard-like quality.

The other categorical rule concerning total economic deprivations provides an even clearer example. As noted earlier, although the Court initially framed this test in rule-like terms, any precision that was intended to inhere in the test was undercut by the same opinion in which the test was established, Lucas v. South Carolina Coastal Commission. ${ }^{369}$ After laying down the test, Justice Scalia first admitted that there remained some question as to what exactly counted as a total economic deprivation:

Regrettably, the rhetorical force of our "deprivation of all economically feasible use" rule is greater than its precision, since the rule does not make clear the "property interest" against which the loss of value is to be measured. When, for example, a regulation requires a developer to leave $90 \%$ of a rural tract in its natural state, it is unclear whether we would analyze the situation as one in which the owner has been deprived of all economically beneficial use of the burdened portion of the tract, or as one in which the owner has suffered a mere diminution in value of the tract as a whole. ${ }^{370}$

Additionally, Justice Scalia created a rather fluid exception to the rule for "restrictions that background principles of the State's law of property and nuisance already place upon land ownership." 371 Just what restrictions might fall within this exception were left unstated, although Justice Scalia indicated that the answer normally would require courts to engage in a nuisance-like inquiry. ${ }^{372}$ Thus, to determine whether categorical treatment really is appropriate, courts would need to consider factors like: (1) the degree of harm to public lands, resources, or neighboring parcels posed by the restricted activities; (2) the social value of those activities; (3) the suitability of the activities to the local area; and (4) the ease with which the alleged harm can be avoided through other measures. ${ }^{373}$ These considerations effectively turn the categorical rule into an indeterminate standard.

There are more examples of this phenomenon, but these aspects of regulatory takings law suffice to make the point. The Court's takings jurisprudence consists of a web of interrelated rules and standards that push takings doctrine as a whole into the "gray area" identified by Professor Korobkin. And inasmuch as the entire

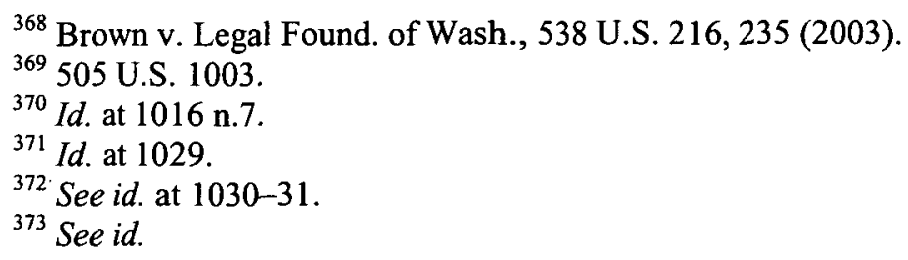


field of regulatory takings is itself an elaborate anti-evasion doctrine, it demonstrates that AEDs act as vehicles of convergence, pushing rules toward standards and vice versa. Because AEDs are ubiquitous in constitutional law, this convergence suggests that the practical distinctions between rule-like and standardlike decision rules are not as meaningful as they may appear. Whichever device is selected, both those subject to it and the Court will adapt in ways that, ultimately, will result in overall doctrine being somewhere in the middle.

\section{The Case for Taking Doctrine Seriously}

A final implication of AEDs is that they reinforce some of the benefits of what one of us has termed the "New Doctrinalism." scholarship differs from older forms of doctrinal study that offered descriptions and analyses of the cases that formed particular constitutional subject areas. Rather, it focuses on the Court's creation and application of devices to implement the Constitution - that is, "how the Court takes general propositions about constitutional meaning and constructs rules that enable it to decide particular cases." 375 This emphasis on doctrinal formation has yielded several advantages in constitutional scholarship, ${ }^{376}$ and we think that the pattern of AEDs highlighted here buttresses the claim that the causes and effects of doctrine creation, as an area of constitutional inquiry, should be taken seriously.

To begin with, it is important to understand what the Court is doing when it decides the cases that come before it. As noted earlier, the Court not only interprets the Constitution to fix its meaning, but it also must decide how to implement its interpretations in actual controversies and provide guidance to lower courts and others who must also implement the law. Recognizing that there is a distinction between interpretation and implementation-even if that distinction is sometimes fuzzy ${ }^{377}$ - sharpens our knowledge of the Court's jurisprudence in ways that transcend tired debates over proper methods of interpretation. That many (if not most) areas of constitutional law are infused with AEDs, for example, draws attention to the Court's struggle to optimize enforcement of constitutional meaning in the face of actors who seek to circumvent that meaning. Regardless of whether one agrees with the Court's underlying interpretation or its methods for arriving at that interpretation, the existence of AEDs reveals something significant: whatever the correct interpretative approach toward or meaning of a constitutional provision, once the meaning is settled upon and implemented, there will almost always be attempts to elude that meaning by promoting form over substance. Further judicial action will then be necessary to ensure that substance triumphs. This pattern (and

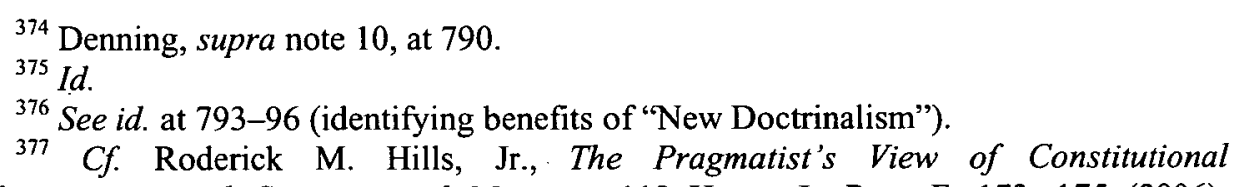
Implementation and Constitutional Meaning, 119 HARV. L. REV. F. 173, 175 (2006), http://www.harvardlawreview.org/media/pdf/hills.pdf (arguing that "the meaning of a constitutional provision is its implementation"). 
whether there are ways to change or improve it) provides a point of common inquiry among scholars, regardless of their predilections over how the Constitution should be interpreted in the first instance.

Similarly, understanding how the Court implements constitutional commands allows for better normative evaluation of the Court's jurisprudence. As one of us has written elsewhere, "Any meaningful normative critique of the Court's work must depend on an accurate descriptive account of what, in fact, the Court does when it decides cases. ${ }^{, 378}$ In this regard, AEDs serve as a reminder that doctrinal formation is not a static, one-step process, but rather is dynamic and ongoing. The Court does not simply craft doctrine and then sit back and watch that doctrine play out; rather, it re-crafts, revises, and reformulates doctrine as new problems present themselves. Recognizing this fact, in itself, allows a more accurate assessment of the Court's work generally.

In like manner, recognizing that many of the Court's decision rules can be explained as efforts to curb evasion permits a more accurate assessment of those rules specifically. For example, as we argue above, it may be that the rules are not as inconsistent as might initially appear. Decisions that seem more results driven at first blush may seem less so upon further inspection, as their anti-evasion characteristics become more evident. In areas where the Court continuously struggles to fashion workable AEDs, the appraisal may be different. It may be that the Court finds itself in such a situation because it has misinterpreted the constitutional imperative itself. These types of normative evaluations become stronger when the Court's doctrine is actually recognized and treated as a valid area of inquiry.

In related fashion, doctrine generally and AEDs specifically provide a platform for considering and evaluating larger questions about the Court's functions and capabilities. Because of their role in optimizing implementation, AEDs raise questions and focus attention on the proper level and means of enforcing the Constitution. Additionally, their existence exposes other issues regarding institutional competence, interbranch relations, and the proper place of the judiciary in a representative democracy.

Last, but certainly not least, understanding AEDs and their role in doctrinal formation has practical value to lawyers and judges as well as to legal academics. Familiarity with these devices, how they generally come to fruition, and how they fit with other decision rules should better enable practitioners to frame arguments and assist lower court judges in navigating the gaps that a particular decision rule leaves open. Doctrinal scholarship of the type we offer here and that others have offered before us could be useful in overcoming, in Judge Edwards's words, "the growing disjunction between legal education and the legal profession."379 Judge Edwards criticized what he believed to be the academy's overemphasis on

${ }^{378}$ Denning, supra note 10, at 794.

${ }^{379}$ Harry T. Edwards, The Growing Disjunction Between Legal Education and the Legal Profession, 91 MiCH. L. REV. 34, 34 (1992). 
"abstract theory at the expense of practical scholarship and pedagogy." ${ }^{380}$ More recently, Chief Justice Roberts has offered his view that a large amount of legal scholarship "isn't of much help to the bar." ${ }^{381}$ Whatever the merits of these critiques, scholarship that pays serious attention to the formation and application of constitutional doctrine helps to answer them.

\section{CONCLUSION}

Constitutional law is replete with anti-evasion doctrines (AEDs)-decision rules taking the form of standards, which backstop or bolster other decision rules that take the form of rules. AEDs optimize enforcement of constitutional principles by raising costs to officials of evasion or violation of those principles by formal compliance with decision rules that leave gaps facilitating substantive evasionwhat we here termed "doctrinal arbitrage." Despite tradeoffs, including AEDs" contribution to doctrinal complexity and inherent limitations on standards as opposed to rules, we have argued that AEDs represent a "mature position" in the risk regulation in which courts engage by encouraging optimal, as opposed to minimal or maximal, protection of constitutional principles. In addition, the identification of AEDs has implications for constitutional doctrine generally. Not only does their creation and application by courts help explain why constitutional doctrine is complex, AEDs also furnish support for the "convergence hypothesis," which suggests rules and standards tend to converge over time. Finally, our Article highlights the benefits of continued study of the doctrinal rules created and applied by courts.

${ }^{380} \mathrm{Id}$.

${ }^{381}$ See Debra Cassens Weiss, Law Prof Responds After Chief Justice Roberts Disses Legal Scholarship, A.B.A. J. (July 7, 2011, 5:29 AM), http://www.abajournal.com/news/ article/law_prof_responds_after_chief_justice_roberts_disses_legal_scholarship/. 